\title{
Climate history of the Southern Hemisphere Westerlies belt during the last glacial-interglacial transition revealed from lake water oxygen isotope reconstruction of Laguna Potrok Aike $\left(52^{\circ} \mathrm{S}\right.$, Argentina)
}

\author{
J. Zhu ${ }^{1}$, A. Lücke ${ }^{1}$, H. Wissel ${ }^{1}$, C. Mayr ${ }^{2,3}$, D. Enters ${ }^{4}$, K. Ja Kim ${ }^{5}$, C. Ohlendorf ${ }^{4}$, F. Schäbitz ${ }^{6}$, and B. Zolitschka ${ }^{4}$ \\ ${ }^{1}$ Institute of Bio- and Geosciences, IBG-3: Agrosphere, Research Center Jülich, 52428 Jülich, Germany \\ ${ }^{2}$ Institute of Geography, University of Erlangen-Nürnberg, 91054 Erlangen, Germany \\ ${ }^{3}$ GeoBio-Center and Dept. of Earth and Environmental Sciences, University of Munich, 80333 Munich, Germany \\ ${ }^{4}$ GEOPOLAR, Institute of Geography, University of Bremen, 28359 Bremen, Germany \\ ${ }^{5}$ Korea Institute of Geoscience and Mineral Resources, 124 Gwahang-no, Yuseong-gu, Daejeon 305-350, Republic of Korea \\ ${ }^{6}$ Seminar für Geographie und ihre Didaktik, University of Cologne, Gronewaldstr. 2, 50931 Cologne, Germany
}

Correspondence to: A. Lücke (a.luecke@ @f-juelich.de)

Received: 24 April 2014 - Published in Clim. Past Discuss.: 26 May 2014

Revised: 30 October 2014 - Accepted: 1 November 2014 - Published: 9 December 2014

\begin{abstract}
The Southern Hemisphere Westerlies (SHW) play a crucial role in large-scale ocean circulation and global carbon cycling. Accordingly, the reconstruction of how the latitudinal position and intensity of the SHW belt changed during the last glacial termination is essential for understanding global climatic fluctuations. The southernmost part of the South American continent is the only continental mass intersecting a large part of the SHW belt. However, due to the scarcity of suitable palaeoclimate archives continuous proxy records back to the last glacial are rare in southern Patagonia. Here, we show an oxygen isotope record from cellulose and purified bulk organic matter of submerged aquatic moss shoots from Laguna Potrok Aike $\left(52^{\circ} \mathrm{S}, 70^{\circ} \mathrm{W}\right)$, a deep maar lake located in semi-arid, extra-Andean Patagonia, covering the last glacial-interglacial transition (26000 to 8500 cal BP). Based on the highly significant correlation between oxygen isotope values of modern aquatic mosses and their host waters and abundant well-preserved moss remains in the sediment record a high-resolution reconstruction of the lake water oxygen isotope $\left(\delta^{18} \mathrm{O}_{\mathrm{lw}-\mathrm{corr}}\right)$ composition is presented. The reconstructed $\delta^{18} \mathrm{O}_{\mathrm{lw} \text {-corr values for }}$ the last glacial are ca. $3 \%$ lower than modern values, which can best be explained by generally cooler air temperatures and changes in the moisture source area, together with the occurrence of permafrost leading to a prolonged lake water
\end{abstract}

residence time. Thus, the overall glacial $\delta^{18} \mathrm{O}_{\mathrm{lw}-\text { corr }}$ level until $21000 \mathrm{cal} \mathrm{BP}$ is consistent with a scenario of weakened or absent SHW at $52^{\circ} \mathrm{S}$ compared to the present. During the last deglaciation, reconstructed $\delta^{18} \mathrm{O}_{\mathrm{lw}-\text { corr }}$ values reveal a significant two-step rise describing the detailed response of the lake's hydrological balance to this fundamental climatic shift. Rapid warming is seen as the cause of the first rise of ca. $2 \%$ in $\delta^{18} \mathrm{O}_{\mathrm{lw} \text {-corr }}$ during the first two millennia of deglaciation (17600 to $15600 \mathrm{cal} \mathrm{BP})$ owing to more ${ }^{18} \mathrm{O}$ enriched precipitation and increasing temperature-induced evaporation. Following this interpretation, an early strengthening of the SHW would not be necessary. The subsequent decrease in $\delta^{18} \mathrm{O}_{\mathrm{lw} \text {-corr }}$ by up to $0.7 \%$ o marks a millennial-scale transition period between 15600 and 14600 cal BP interpreted as the transition from a system driven by temperature-induced evaporation to a system more dominated by wind-induced evaporation. The $\delta^{18} \mathrm{O}_{\mathrm{lw}-\text { corr }}$ record resumes its pronounced increase around $14600 \mathrm{cal} \mathrm{BP}$. This further cumulative enrichment in ${ }^{18} \mathrm{O}$ of lake water could be interpreted as response to strengthened wind-driven evaporation as induced by the intensification and establishment of the SHW at the latitude of Laguna Potrok Aike $\left(52^{\circ} \mathrm{S}\right)$ since $14600 \mathrm{cal} \mathrm{BP}$. $\delta^{18} \mathrm{O}_{\mathrm{lw}-\text { corr }}$ approaching modern values around $8500 \mathrm{cal} \mathrm{BP}$ reflect that the SHW exerted their full influence on the lake 
water balance at that time provoking a prevailing more arid steppe climate in the Laguna Potrok Aike region.

\section{Introduction}

Studying the climate evolution from the last glacial towards the current interglacial enables us to better understand the responses of the climate system to external and internal forcing without anthropogenic impacts. Palaeoclimatic sites in southern South America (Patagonia) play an important role for climate reconstructions, as Patagonia is the only continental mass intersecting the core of the Southern Hemisphere Westerlies (SHW). The SHW control large-scale ocean ventilation and carbon cycling and could have played a decisive role in driving the global deglacial warming during the last glacial termination (Toggweiler et al., 2006; Anderson et al., 2009; Denton et al., 2010; Mayr et al., 2013). However, reconstructing the position and intensity of the SHW during the last glacial-interglacial transition is limited, because the Andean area of southern Patagonia, where most palaeoclimate sites are located, was covered by the Patagonian Ice Sheet during the Last Glacial Maximum (LGM). The available continuous proxy records in the region south of $45^{\circ} \mathrm{S}$ are mostly restricted to the periods since the late glacial and, especially, the Holocene (e.g. Ariztegui et al., 2010; Markgraf and Huber, 2010; Moreno et al., 2010, 2012; Kilian and Lamy, 2012). The scarcity of long and continuous terrestrial records in these southern latitudes leaves a gap for linking Antarctic ice cores with low southern latitude and Northern Hemispheric records.

A key location to bridge this gap is Laguna Potrok Aike, a deep maar lake located in southern extra-Andean Patagonia $\left(52^{\circ} \mathrm{S}, 70^{\circ} \mathrm{W}\right)$. The site was investigated within the framework of the interdisciplinary multiproxy ICDP project "Potrok Aike maar lake sediment archive drilling project" (PASADO) and provided a lake sediment record reaching back more than 50000 years (Ohlendorf et al., 2011; Kliem et al., 2013b; Zolitschka et al., 2013). Palynological and geochemical studies based on the Laguna Potrok Aike sediments have shown the long-term environmental and climatic changes in southern Patagonia throughout the last glacialinterglacial cycle and shed light on the behaviour of the SHW during this transition (e.g. Recasens et al., 2012; Hahn et al., 2013; Mayr et al., 2013; Zhu et al., 2013).

The reconstruction of the intensity of the SHW in southern Patagonia is usually based on the correlation between wind strength and precipitation amount (Kilian and Lamy, 2012). As revealed by Garreaud et al. (2013), the humid western side of the Andes exhibits a significantly positive correlation between precipitation and westerly wind strength, while the semi-arid eastern side of the Andes shows a distinct negative correlation. The significance of the relationship between precipitation and westerly wind intensity on the semi-arid lee- ward side of the southern Andes is in fact not as strong as it is on the windward side (Wagner et al., 2007; Garreaud et al., 2013), likely as a consequence of overall low and variable annual precipitation.

However, the SHW affect water balances of lakes on the leeward side of the Andes not only through their linkage with precipitation amount but also by evaporative enrichment, which is also controlled by wind intensity. Thus, the modern oxygen isotope composition of Laguna Potrok Aike's lake water $\left(\delta^{18} \mathrm{O}_{\mathrm{lw}}\right)$ is mainly controlled by the $\delta^{18} \mathrm{O}$ of regional precipitation and evaporative processes (Mayr et al., 2007, 2013). The former is dependent on air temperature during rainfall events and $\delta^{18} \mathrm{O}$ of precipitation of different moisture sources that are in turn associated with the strength of westerly winds. The $\delta^{18} \mathrm{O}$ of precipitation brought by easterly winds from the Atlantic is considerably more enriched in ${ }^{18} \mathrm{O}$ than that from the Pacific over the southern Andes (Mayr et al., 2007). Evaporative processes in arid southeastern Patagonia are driven by insolation and westerly winds. Since the processes controlling Laguna Potrok Aike's $\delta^{18} \mathrm{O}_{\mathrm{lw}}$ are largely related to changes in SHW intensity, a sediment proxy allowing for the reconstruction of past $\delta^{18} \mathrm{O}_{\mathrm{lw}}$ composition provides valuable insights into the SHW evolution at high southern latitudes.

Over recent decades, it has been widely recognized that the oxygen isotope composition of aquatic cellulose $\left(\delta^{18} \mathrm{O}_{\text {cell }}\right)$ is a reliable recorder of host water $\delta^{18} \mathrm{O}$ values (e.g. Epstein et al., 1977; DeNiro and Epstein, 1981; Sternberg, 1989, 2009). Furthermore, results from laboratory (Sauer et al., 2001) and field studies (Mayr et al., 2013) demonstrate convincingly that $\delta^{18} \mathrm{O}$ of cellulose extracted from submerged aquatic mosses are highly correlated to their host waters owing to the absence of uncertainties related to evapotranspiration. However, achieving a high-resolution $\delta^{18} \mathrm{O}_{\text {cell }}$ record could be impeded, because oxygen isotope analysis of moss cellulose requires large quantities of moss remains for cellulose extraction. An approach to tackle this problem is the isotope analyses of purified bulk organic matter (OM) of preserved aquatic moss shoots, which needs much less material, and can potentially improve the temporal resolution of palaeoclimatic reconstructions based on the moss cellulose alone without losing palaeoclimatic information (Zhu et al., 2014).

In a previous study, $\delta^{18} \mathrm{O}_{\text {cell }}$ values of aquatic moss debris were used to infer $\delta^{18} \mathrm{O}_{\mathrm{lw}}$ of Laguna Potrok Aike over the last deglaciation (Mayr et al., 2013). In the present study, we used hand-picked subfossil shoots of a single aquatic moss species from sediment sections covering the last glacial-interglacial transition period to generate a composite record of the $\delta^{18} \mathrm{O}_{\mathrm{lw}}$ inferred from purified bulk moss $\mathrm{OM}$ and extracted cellulose fractions. The aims of the study are (1) to present a high-resolution $\delta^{18} \mathrm{O}_{\mathrm{lw}}$ record of Laguna Potrok Aike for the period containing large global climatic shifts by employing isotope proxies of aquatic mosses, (2) to highlight climatic changes on the southern South American continent during 


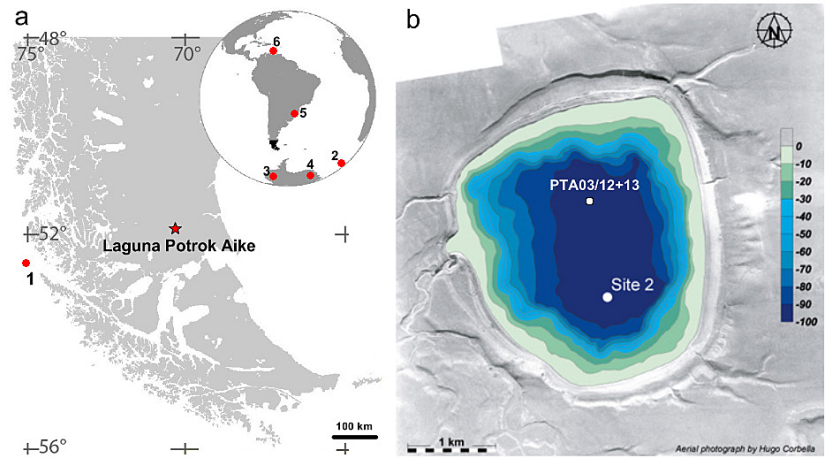

Figure 1. (a) Location of Laguna Potrok Aike (red star) in southern Patagonia indicated by the black area on the inserted map. Location of sites presented in Fig. 9: 1, MD07-3128 offshore the Chilean coast (Caniupán et al., 2011); 2, TN057-13-4PC in the southern Atlantic (Anderson et al., 2009); 3, WDC in West Antarctica (WAIS Divide Project Members, 2013); 4, EDML of East Antarctica (EPICA Community Members, 2006); 5, Botuverá Cave in southern Brazil (Wang et al., 2007); and 6, Cariaco Basin (Deplazes et al., 2013). (b) Sediment samples investigated in the present study derive from the drilling site 2 shown on the bathymetric map of Laguna Potrok Aike inserted into an aerial photography (provided by Hugo Corbella). At site 2, hydraulic piston cores were taken in 2008 within the framework of PASADO. The piston core PTA03/12+13 taken in 2003 has been used for the reconstruction of oxygen isotope composition of lake water in Mayr et al. (2013).

the last glacial-interglacial transition and (3) to evaluate the SHW' impact on factors determining the $\delta^{18} \mathrm{O}_{\mathrm{lw}}$ of Laguna Potrok Aike.

\section{Regional setting}

The maar Laguna Potrok Aike is located on the southern side of the Río Gallegos Valley in the Pali Aike Volcanic Field in southern Patagonia, Argentina $\left(51^{\circ} 58^{\prime} \mathrm{S}, 70^{\circ} 23^{\prime} \mathrm{W}\right.$; $113 \mathrm{~m}$ a.s.1.; Fig. 1a). The bedrock of the lake area is dominated by fine-grained molasse-type fluvial sediments (Lower Miocene Santa Cruz Formation) that are about $660 \mathrm{~m}$ thick in the investigated area (Zolitschka et al., 2006; Coronato et al., 2013). The nearly flat and broad surface is mainly overlain by degraded late Miocene and early Pleistocene basaltic lava flows and tablelands and early Pleistocene fluvioglacial deposits (Coronato et al., 2013). Glaciers of the last glacial were restricted to the western Río Gallegos Valley and to the southern Strait of Magellan and did not reach the Laguna Potrok Aike area (Coronato et al., 2013). The regional vegetation is a dry Magellanic steppe with grasses, dwarf shrubs and bushes (Wille et al., 2007).

The near-circular maar lake originates from a phreatomagmatic eruption with a ${ }^{40} \mathrm{Ar} /{ }^{39} \mathrm{Ar}$ age of $770 \pm 240 \mathrm{ka} \mathrm{BP}$ (Zolitschka et al., 2006) and has a flat lake floor (Fig. 1b). Under present-day conditions, Laguna Potrok Aike is a
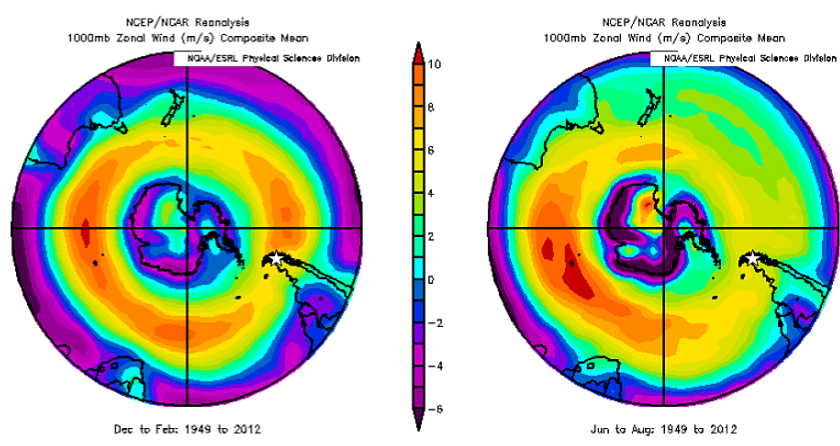

Figure 2. Mean near-surface $(1000 \mathrm{mb})$ zonal wind $\left(\mathrm{m} \mathrm{s}^{-1}\right)$ in the Southern Hemisphere for austral summer (left) and winter months (right) based on NCEP/NCAR Reanalysis. Location of Laguna Potrok Aike is indicated by white stars. Data source: http://www. esrl.noaa.gov/psd/cgi-bin/data/composites/printpage.pl; last access: 19 August 2014.

phosphorous-rich and subsaline lake with a surface area of $7.58 \mathrm{~km}^{2}$ and a maximum depth of $100 \mathrm{~m}$ (Zolitschka et al., 2006). The lake has only episodic inflows through gullies and canyons from a catchment area of about $200 \mathrm{~km}^{2}$. According to isotope modelling calculations, about $60 \%$ of the water entering groundwater-fed Laguna Potrok Aike evaporates (Mayr et al., 2007). The water body circulates constantly under the prevailing strong west-wind conditions, which inhibits the development of summer stratification in the water column. Subaerial and submerged palaeoshorelines indicate pronounced lake-level fluctuations resulting from past hydrological changes (Zolitschka et al., 2006; Haberzettl et al., 2008; Anselmetti et al., 2009; Gebhardt et al., 2012; Kliem et al., 2013a).

Dense aquatic vegetation predominantly formed by Potamogeton pectinatus and Myriophyllum cf. quitense covers the lake floor from a water depth of ca. 1.5 to $15 \mathrm{~m}$ (Wille et al., 2007). Aquatic mosses (Drepanocladus perplicatus) and Ruppia sp. were also observed in the littoral zone during snorkelling explorations. However, a detailed survey of the recent limnic habitat has so far not been conducted.

Laguna Potrok Aike is located on the leeward side of the southern Andes and in the core of the modern SHW (Fig. 2). The regional cool and semi-arid climate is characterized by a low precipitation to evaporation ratio and predominant strong westerly wind reaching more than $10 \mathrm{~m} \mathrm{~s}^{-1}$ during austral summers (Garreaud et al., 2013; Ohlendorf et al., 2013). Annual precipitation on the leeward side of the southern Andes can be less than $200 \mathrm{~mm}$ owing to strong rain-shadow effects. An even seasonal distribution of precipitation in this region was attributed to the influence of relatively humid air masses from the Atlantic (Paruelo et al., 1998; Schneider et al., 2003; Garreaud et al., 2013). Mean annual precipitation at Laguna Potrok Aike is around $200 \mathrm{~mm}$ during the period from 2000 to 2011 , being nearly $300 \mathrm{~mm}$ in wet years and only around $150 \mathrm{~mm}$ in dry years (Ohlendorf et al., 2013). 
By comparison, evaporation rates from the surface of the lake can be more than $1200 \mathrm{~mm}$ per year and show clear seasonal variations with high rates during austral summers and low rates during austral winters (Ohlendorf et al., 2013). This seasonal pattern results from seasonal variation of relative humidity with high values (up to $85 \%$ ) during austral winters and low values (down to $30 \%$ ) during austral summers (Ohlendorf et al., 2013). Proximity to the Antarctic continent and oceans causes cool summer and mild winter temperatures in southern Patagonia. Mean temperatures of austral summer (DJF) and winter (JJA) recorded at the local weather station at Laguna Potrok Aike are 13 and $2{ }^{\circ} \mathrm{C}$, respectively, resulting in an annual mean temperature of $7.5^{\circ} \mathrm{C}$ (Ohlendorf et al., 2013).

Whereas meteorological parameters such as wind speed, air temperature and relative humidity exhibit a clear seasonal variation pattern at Laguna Potrok Aike, $\delta^{18} \mathrm{O}_{\mathrm{lw}}$ values show relatively little interannual and intra-annual isotopic variations within a range between -3.4 and $-3.9 \%$ and remain constant with increasing water depth, presumably due to groundwater recharge and strong wind-driven circulation in the whole water column (Mayr et al., 2007). $\delta^{18} \mathrm{O}_{\mathrm{lw}}$ values of lakes and ponds in the southern Patagonian steppe plot along a local evaporation line, regardless of depth, mixing, surface area and type, suggesting that isotope composition of the main source waters (precipitation and groundwater) is similar for all water bodies and evaporation is a main driver of the $\delta^{18} \mathrm{O}_{\mathrm{lw}}$ (Mayr et al., 2007).

\section{Material and methods}

\subsection{Material}

In 2008 sediment cores were retrieved from two drilling sites in Laguna Potrok Aike within the framework of the PASADO project (Ohlendorf et al., 2011; Zolitschka et al., 2013; Fig. 1b). Sediment samples used in this study are from the composite profile $5022-2 \mathrm{CP}$ of site 2 , which has a composite depth (cd) of $106 \mathrm{~m}$, consisting of undisturbed pelagic sediments, volcanic tephra layers and mass movement sediments that resulted from lake-internal sediment redistribution. The composite profile is divided into five lithological units based on the prevailing sedimentary structures and frequency of deposits of mass movement (Kliem et al., 2013b). Mass movement deposits and tephra layers were removed from the composite profile resulting in an eventcorrected composite depth profile (cd-ec) of $45.8 \mathrm{~m}$ (Kliem et al., 2013b). The sediment section investigated in this study ranges between ca. 10 and $30 \mathrm{~m}(\mathrm{~cd})$ or between 9.6 and $21.4 \mathrm{~m} \mathrm{(cd-ec)}$ and consist of lithological unit B and C-1 (Fig. 3). Both unit B and C-1 mainly comprise pelagic laminated silts intercalated with thin, fine sand and coarse silt layers originating from mass movement deposits. Pelagic silts are poorly laminated in unit $\mathrm{C}-1$, which has a greenish and

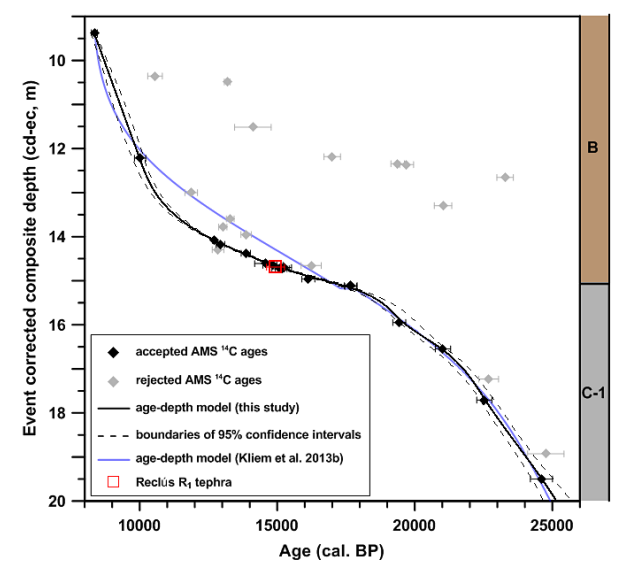

Figure 3. Age-depth model for the sediment section between 9 and $20 \mathrm{~m}$ event-corrected composite depth (cd-ec) from the composite profile 5022-2CP of Laguna Potrok Aike (see Table 1 for details). The age-depth model used in the present study is shown as a black line which is constructed with clam 2.2 applying a smooth spline with a smoothing level of 0.5 (Blaauw, 2010). Dashed lines represent the upper and lower boundary of $95 \%$ confidence intervals. The accepted AMS ${ }^{14} \mathrm{C}$ ages are shown as black diamonds and the rejected ones in grey. Error bars represent the range of calibrated ages at $95 \%$ confidence intervals. The previous age-depth model by Kliem et al. (2013b) is given as a blue line. The red open square represents the depth of the Reclús $R_{1}$ tephra. Its ${ }^{14} \mathrm{C}$ age from $\mathrm{Mc}$ Culloch et al. (2005) is recalibrated with CALIB 7.0 using SHCal13 (Hogg et al., 2013). Error bars are given for $2 \sigma$ age range. Two lithological units (see text for details) occurring in the investigating depth range are shown on the right.

bluish-grey colour spectrum compared to dark- and lightgrey laminations of unit B (Kliem et al., 2013b). A $0.2 \mathrm{~m}$ long sediment section between 20.2 and $20.4 \mathrm{~m}$ (cd) has been newly identified as mass movement deposits and therefore removed from the event-corrected composite depth profile.

Well-preserved moss fragments occurred frequently in the sediments. There are mainly three species: Drepanocladus perplicatus (Amblystegiaceae), Blindia inundata (Seligeriaceae) and Vittia pachyloma (Amblystegiaceae) (see Fig. 2 in Zhu et al., 2014). These moss species were all reported as submerged aquatic species (Ochyra and Lightowlers, 1988; Hedenäs, 1997; Frahm, 2001). D. perplicatus fragments were dominant in most sediment samples. Mainly shoots and individual leaves were found in the sediments. Some shoots were preserved with attached leaves, but in many cases leaf laminae were completely eroded before sedimentation and only costae remained on the central axis of the shoot.

\subsection{Age-depth model}

An age-depth model based mostly on AMS radiocarbon dating of aquatic mosses has been previously established for the entire composite profile 5022-2CP (Kliem et al., 2013b). To constrain this existing model in the investigated sediment 
Table 1. AMS ${ }^{14} \mathrm{C}$ ages for the modelled event-corrected sediment depth in the range of 9.37-26.48 $\mathrm{m}$ (cd-ec) for 5022-2CP of Laguna Potrok Aike. All ${ }^{14} \mathrm{C}$ ages derive from samples collected in pelagic sediment sections. Ranges of calibrated ages (at $95 \%$ confidence intervals, $2 \mathrm{~s}$ ) are the output of age-modelling software clam 2.2 (Blaauw, 2010) applying the SHCal13 calibration curve (Hogg et al., 2013) and smoothed spline with a smoothing level of 0.5 . Accepted ${ }^{14} \mathrm{C}$ ages are shown in bold.

\begin{tabular}{|c|c|c|c|c|c|c|c|c|c|}
\hline Lab. no.* & $\begin{array}{r}\text { Sediment } \\
\text { depth }(\mathrm{mcd})\end{array}$ & $\begin{array}{r}\text { Event-corrected sediment } \\
\text { depth (m cd-ec) }\end{array}$ & $\begin{array}{r}{ }^{14} \mathrm{C} \text { age } \\
(\mathrm{BP})\end{array}$ & $\begin{array}{r}\text { Error } \\
( \pm)\end{array}$ & $\begin{array}{r}\delta^{13} \mathrm{C} \\
(\% o)\end{array}$ & $\begin{array}{r}\mathrm{C} \text { mass } \\
(\mathrm{mg})\end{array}$ & Sample description & $\begin{array}{r}\text { Range of calibrated } \\
\text { ages }(2 \sigma)\end{array}$ & $\begin{array}{r}\text { Median } \\
\text { probability }\end{array}$ \\
\hline Poz-8392a & 9.69 & 9.37 & 7580 & 50 & -28.3 & 2.56 & Stems of aquatic moss & $8203-8421$ & 8355 \\
\hline Poz-48915 & 10.81 & 10.35 & 9390 & 90 & -28.7 & 1.74 & Bulk aquatic moss tissues & $10254-10784$ & 10557 \\
\hline AA93659 & 10.95 & 10.49 & 11379 & 57 & -25.6 & - & Bulk sediment & $13079-13292$ & 13185 \\
\hline AA93660 & 12.22 & 11.52 & 12200 & 200 & -29.4 & - & Wood, plant fragments & $13574-14902$ & 14115 \\
\hline AA93661 & 12.99 & 12.18 & 14042 & 70 & -25.3 & - & Bulk sediment & $16674-17276$ & 17000 \\
\hline Poz-5985 ${ }^{\mathrm{a}}$ & 13.04 & 12.22 & 8930 & $\mathbf{5 0}$ & -18.9 & 2.28 & Tuco-tuco bone & $9780-10188$ & 10016 \\
\hline AA93662 & 14.06 & 12.34 & 16101 & 84 & -25.5 & - & Wood, transparent shell fragments & $19122-19612$ & 19378 \\
\hline Poz-48917 & 14.08 & 12.36 & 16360 & 90 & -29.3 & 1.18 & Bulk aquatic moss tissues & $19476-19980$ & 19704 \\
\hline Poz-49760 & 14.37 & 12.66 & 19380 & 100 & -27.3 & 1.77 & Bulk aquatic moss tissues & $22983-23581$ & 23284 \\
\hline Poz- $8548^{\mathrm{a}}$ & 14.78 & 13.00 & 10240 & 60 & 8.4 & 3.61 & Calcite fraction of bulk sample & $11611-12067$ & 11872 \\
\hline Poz-48918 & 15.07 & 13.30 & 17460 & 100 & -28.5 & 3.14 & Bulk aquatic moss tissues & $20717-21355$ & 21026 \\
\hline Poz-49761 & 15.37 & 13.60 & 11490 & 60 & -25.1 & 1.50 & Bulk aquatic moss tissues & $13147-13428$ & 13291 \\
\hline Poz- $8396^{\mathrm{a}}$ & 15.55 & 13.78 & 11200 & 60 & -30.0 & 1.69 & Stems of aquatic moss & $12831-13130$ & 13023 \\
\hline Poz-48919 & 15.73 & 13.95 & 12050 & 70 & -31.6 & 1.41 & Bulk aquatic moss tissues & $13712-14089$ & 13868 \\
\hline Poz-49763 & 15.87 & 14.08 & 10840 & 60 & -28.8 & 2.03 & Bulk aquatic moss tissues & $12654-12790$ & 12711 \\
\hline Poz-48920 & 15.95 & 14.18 & 11120 & 70 & -33.1 & 2.97 & Bulk aquatic moss tissues & $12771-13081$ & 12935 \\
\hline Poz-49764 & 16.15 & 14.38 & 12040 & 60 & -27.4 & 1.70 & Bulk aquatic moss tissues & $13719-14054$ & 13856 \\
\hline Poz-8397 ${ }^{\mathrm{a}}$ & 16.40 & 14.61 & 12490 & 70 & -31.2 & 1.60 & Stems of aquatic moss & $14198-15001$ & 14583 \\
\hline Poz-49765 & 16.42 & 14.65 & 12590 & 60 & -27.4 & 1.52 & Bulk aquatic moss tissues & $14409-15139$ & 14844 \\
\hline Poz-5072a & 16.48 & 14.70 & 12850 & 70 & -25.8 & 2.64 & Stems of aquatic moss & $15068-15575$ & 15267 \\
\hline Poz-49022 & 18.28 & 14.73 & 12720 & 70 & -29.2 & 2.43 & Bulk aquatic moss tissues & $14753-15304$ & 15082 \\
\hline AА93666 & 18.28 & 14.73 & 12783 & 64 & -27.3 & - & Plant fragments & $14906-15415$ & 15179 \\
\hline Poz-48922 & 18.40 & 14.85 & 13530 & 70 & -27.6 & 1.82 & Bulk aquatic moss tissues & $14409-15139$ & 16235 \\
\hline Poz-5073 $^{\mathrm{a}}$ & 18.51 & 14.96 & 13450 & 70 & -28.7 & 2.69 & Stems of aquatic moss & $15881-16354$ & 16132 \\
\hline Poz-48923 & 18.67 & 15.11 & 14540 & 80 & -29.3 & 1.58 & Bulk aquatic moss tissues & $17450-17913$ & 17671 \\
\hline Poz-37017 & 18.69 & 15.13 & 14540 & 70 & -27.6 & 1.56 & Stems of aquatic moss & $17465-17900$ & 17672 \\
\hline Poz-48925 & 21.13 & 15.94 & 16150 & 80 & -24.0 & 1.30 & Bulk aquatic moss tissues & $19190-19662$ & 19435 \\
\hline Poz-37022 ${ }^{\mathrm{b}}$ & 22.09 & 16.54 & 17460 & 80 & -29.2 & 1.63 & Stems of aquatic moss & $20760-21317$ & 21023 \\
\hline AA93669 & 22.57 & 17.23 & 18850 & 170 & -26.3 & - & Bulk sediment & $22363-23080$ & 22686 \\
\hline Poz-37007 ${ }^{\mathrm{b}}$ & 23.25 & 17.70 & 18700 & 120 & -39.9 & 0.91 & Stems of aquatic moss & $22304-22852$ & 22527 \\
\hline AA93670 & 25.01 & 18.93 & 20600 & 270 & -26.0 & - & Bulk sediment & $24118-25442$ & 24762 \\
\hline Poz-37020 ${ }^{\mathrm{b}}$ & 27.20 & 19.50 & 20490 & 120 & -28.0 & 1.11 & Stems of aquatic moss & $24242-25045$ & 24604 \\
\hline Poz-34236 ${ }^{\text {bc }}$ & 36.38 & 26.48 & 25110 & 180 & -25.0 & 1.45 & Stems of aquatic moss & $28713-29531$ & 29108 \\
\hline
\end{tabular}

* Poz: Poznan Radiocarbon Laboratory; AA: NSF-Arizona AMS Laboratory. ${ }^{a}$ Haberzettl et al. (2007). ${ }^{\mathrm{b}}$ Kliem et al. (2013b).

${ }^{c}$ Not shown in Fig. 3, but serving as connection point with previous age-depth model by Kliem et al. (2013b).

section, 22 additional samples of bulk aquatic moss and other organic matter were selected from the undisturbed pelagic sediment sections and sent to the Poznan Radiocarbon Laboratory and the NSF-Arizona AMS Laboratory for AMS ${ }^{14} \mathrm{C}$ determination (see Table 1 for detailed sample information). The age-depth model used in the present study (Fig. 3) was constructed with the software clam 2.2 (Blaauw, 2010), using the SHCal13 calibration curve (Hogg et al., 2013) and smoothed spline interpolation with a smoothing level of 0.5 . The modelled depth range is from 9.4 to $26.5 \mathrm{~m}$ (cd-ec), including the sample Poz-8392 on the top and Poz-34236 on the bottom serving as connection points with the previous age-depth model by Kliem et al. (2013b). In total, 34 AMS ${ }^{14} \mathrm{C}$ dates from pelagic sediment sections were available for the modelled depth range (Table 1, Fig. 3).

There is a strong scatter between calibrated ages and event-corrected composite depth, particularly between 10 and $13.5 \mathrm{~m} \mathrm{cd-ec} \mathrm{(Fig.} \mathrm{3).} \mathrm{In} \mathrm{order} \mathrm{to} \mathrm{obtain} \mathrm{a} \mathrm{reliable} \mathrm{age-}$ depth model, only the youngest ages were included in the age-depth model under the assumption that older than ex- pected ${ }^{14} \mathrm{C}$ ages are the result of admixture of reworked old organic matter to the young counterparts. The main difference between the present and the previous age-depth model by Kliem et al. (2013b) is in the depth range between 12 and $15 \mathrm{~m}$ (cd-ec), where the calibrated ages derived from the present age-depth model are up to 1700 years younger than in the previous one (Fig. 3). We argue that the present age model based on more AMS ${ }^{14} \mathrm{C}$ dates tends to be more reliable in this depth range based on a $1.5 \mathrm{~m}$ thick sediment section consisting of a multi-layered volcanic tephra bed at the depth from 16.8-18.2 m (cd) corresponding to the event-corrected composite depth of $14.7 \mathrm{~m} \mathrm{(cd-ec)}$ (Wastegård et al., 2013). Chemical analyses indicated that this volcanic tephra is the $R_{1}$ tephra derived from the volcano Reclús (Wastegård et al., 2013). Based on high-resolution dating of $1 \mathrm{~mm}$ peat layers immediately beneath the Reclús tephra layer at two sites at the Strait of Magellan, McCulloch et al. (2005) provided a weighted pooled mean age of $12638 \pm 60{ }^{14} \mathrm{C}$ years BP for the Reclús $R_{1}$ tephra. We recalibrated this ${ }^{14} \mathrm{C}$ age with CALIB 7.0 using SHCal13 (Hogg et 
al., 2013) and obtained a $2 \sigma$ range of calibrated ages between 14559 and $15210 \mathrm{cal} \mathrm{BP}$ (Fig. 3). Stern (2008) and Sagredo et al. (2011) reported nearly the same ages. According to the new age-depth model, the depth of $14.7 \mathrm{~m}$ (cd-ec) has an age of $15102 \mathrm{cal}$ BP well within the reported age range of the Reclús $R_{1}$ tephra, whereas the previous model gives a considerably older age of $16034 \mathrm{cal}$ BP (Kliem et al., 2013b). The higher reliability of the present age-depth model is validated by its consistency with the independently dated tephra ages. We refer to the refined age-depth model for the composite profile 5022-2CP of site 2 as version 3.1 (v3.1). This refined age-depth model is composed of 10 previously published and 8 new radiocarbon ages for the depth interval from 26.5 to $9.4 \mathrm{~m}$ (cd-ec). Outside of this depth interval the agedepth model is identical with the age-depth model (v3) of Kliem et al. (2013b).

According to the new age-depth model (v3.1) the investigated sediment section covers the last glacial-interglacial transition from 26000 to $8500 \mathrm{cal} \mathrm{BP}$ and ranges from the LGM to the early Holocene. The temporal boundary between lithological units B and C-1 is around $17600 \mathrm{cal} \mathrm{BP}$.

\subsection{Laboratory methods}

\subsubsection{Isolation of moss remains}

To acquire as many moss remains as possible, ca. $10 \mathrm{~cm}^{3}$ of sediments from every sample was screened. Each freezedried sediment sample was moistened with deionized water, placed on a magnetic stirrer and stirred for $2 \mathrm{~h}$ to disaggregate the material. Subsequently, the sample was carefully sieved through a $200 \mu \mathrm{m}$ sieve to obtain the coarse plant-debris fraction. The sieve fraction $(>200 \mu \mathrm{m})$ consists mainly of subfossil plant fragments such as shoots and leaves of mosses and remains of vascular plants, which were usually well preserved. Moss shoots were hand-picked from the coarse sieve fraction under a binocular microscope. To gain species-specific moss samples, we tried to pick only shoots of $D$. perplicatus. However, due to the similarity of the fragments of D. perplicatus and V. pachyloma and some not easily identifiable branches without leaves, an admixture of such moss fragments to the $D$. perplicatus samples cannot be ruled out. The remaining plant material in the coarse sieve fraction (>200 $\mu \mathrm{m}$ ) could contain fragments of B. inundata, V. pachyloma and other unidentifiable mosses and individual leaves of $D$. perplicatus, as well as remains of aquatic and possibly terrestrial vascular plants, and is termed "residue" hereafter.

Each moss sample was first treated with a mixture of $\mathrm{HCl}$ and HF (both $10 \%$ ) and left for $16 \mathrm{~h}$ at room temperature to completely remove attached carbonates and minerogenic components. Samples were then rinsed with deionized water three times to remove reagents and remaining clastic matter and freeze-dried. The cleaned moss samples were weighed and homogenized by cutting the moss branches into fine segments with scissors to avoid loss of fine moss material com- pared to milling. Bulk OM of moss branches was first analysed for $\delta^{18} \mathrm{O}$ and $\delta^{13} \mathrm{C}$ values, before cellulose extraction was conducted. HCl-HF treatment of moss tissue prior to cellulose extraction has no effect on the $\delta^{18} \mathrm{O}$ and $\delta^{13} \mathrm{C}$ values of cellulose (Zhu et al., 2014).

\subsubsection{Cellulose extraction}

Cellulose was extracted from moss shoots and the residue fraction using the cuprammonium solution (CUAM) method that has shown high reliability in yielding clean and pure cellulose from freshwater sediments, peat mosses and aquatic plants (Wissel et al., 2008; Moschen et al., 2009; Zhu et al., 2014). This method produces pure cellulose by dissolving and re-precipitating cellulose from whole plant material. Samples were first bleached with $\mathrm{NaClO}_{2}(7 \%)$ acidified with concentrated acetic acid $(96 \%)$ in a water bath for $10 \mathrm{~h}$ at $60^{\circ} \mathrm{C}$. The residual material was washed two times with hot deionized water $\left(\sim 70^{\circ} \mathrm{C}\right)$ to remove the reagents and freeze-dried. The dry sample was mixed with ca. $30 \mathrm{~mL}$ of CUAM solution $\left(15 \mathrm{~g} \mathrm{~L}^{-1}\right)$ while placed in a dark room and stirred on a magnetic stirrer for $6 \mathrm{~h}$ and then left for a further $10 \mathrm{~h}$ at room temperature to completely dissolve the cellulose. To separate the not dissolved non-cellulose material, the cellulose solution was carefully decanted into a centrifuge tube and treated with $3 \mathrm{~mL}$ of $\mathrm{H}_{2} \mathrm{SO}_{4}(20 \%)$ for cellulose precipitation. The white precipitated cellulose was then rinsed three times with deionized water and freeze-dried.

\subsubsection{Stable isotope measurements}

For carbon isotope analyses, an amount of moss OM or cellulose equivalent to $100 \mu \mathrm{g}$ of carbon was weighed into tin capsules. Samples were combusted at $1020^{\circ} \mathrm{C}$ using an elemental analyser (Thermo Scientific Flash 2000) interfaced online with an isotope ratio mass spectrometer (Thermo Scientific Delta V Advantage). Carbon content was determined by peak integration of mass-to-charge ratio $(\mathrm{m} / \mathrm{z}) 44,45$ and 46 and calibrated against elemental standards. For oxygen isotope analyses, an amount of moss OM or cellulose providing $125 \mu \mathrm{g}$ of oxygen was weighed into silver capsules. Immediately prior to oxygen isotope analysis, samples were placed overnight $(16 \mathrm{~h})$ in a vacuum drier at $100^{\circ} \mathrm{C}$ to avoid analytical bias by adsorbed air moisture. Vacuumdried samples were then pyrolysed at $1450{ }^{\circ} \mathrm{C}$ in a hightemperature pyrolysis analyser (HTO, HEKAtech) and measured online with a coupled isotope ratio mass spectrometer (Micromass IsoPrime). Oxygen content was determined by peak integration of $m / z 28,29$ and 30, and calibrated against elemental standards. Each sample was measured at least two times for both carbon and oxygen isotopes. Isotope ratios are expressed as $\delta$ values in per mil (\%o), where $\delta=\left(R_{\text {sample }} / R_{\text {standard }}-1\right) \times 1000$, with $\mathrm{R}_{\text {sample }}$ and $\mathrm{R}_{\text {standard }}$ as isotope ratios $\left({ }^{13} \mathrm{C} /{ }^{12} \mathrm{C},{ }^{18} \mathrm{O} /{ }^{16} \mathrm{O}\right)$ of samples and standards, respectively. Isotope values are reported on the VPDB 
scale for carbon and the VSMOW scale for oxygen. Laboratory standards were inserted between samples to monitor the performance of the instrument and for calibration purposes. The standards USGS24 $(-16.05 \%)$, IAEA-CH$6(-10.45 \%)$ and IAEA-CH-7 $(-32.15 \%)$ were used for calibration of carbon isotope ratios of laboratory standards and samples, respectively (Coplen et al., 2006). The benzoic acid standards IAEA-601 $(23.14 \pm 0.19 \%$ o $)$ and IAEA-602 $(71.28 \pm 0.36 \%$ ) (Brand et al., 2009) were used for calibration of oxygen isotope ratios of laboratory standards and samples, respectively. The overall precision of replicate analyses was better than $\pm 0.1 \%$ o for carbon and $\pm 0.3 \%$ o for oxygen isotope ratios. Ratios of carbon and oxygen content $(\mathrm{C} / \mathrm{O})$ of moss $\mathrm{OM}$ and cellulose were calculated on a weight base.

\subsection{Reconstructed lake water $\delta^{18} \mathrm{O}$ values}

Modern field calibration data sets published in Zhu et al. (2014) were used to reconstruct the $\delta^{18} \mathrm{O}_{\mathrm{lw}}$ values from both bulk OM $\left(\delta^{18} \mathrm{O}_{\mathrm{OM}}\right)$ and cellulose $\left(\delta^{18} \mathrm{O}_{\text {cell }}\right)$ of submerged aquatic mosses as well as the residue fraction applying the following equations:

$\delta^{18} \mathrm{O}_{\mathrm{lw}}=1.156( \pm 0.036) \delta^{18} \mathrm{O}_{\mathrm{OM}}-32.2( \pm 0.8)$,

$\delta^{18} \mathrm{O}_{\mathrm{lw}}=1.028( \pm 0.021) \delta^{18} \mathrm{O}_{\text {cell }}-30.4( \pm 0.5)$.

The uncertainty of the prediction (standard error of the regression) is $0.4 \%$ for Eq. (1) and $0.3 \%$ for Eq. (2) (Zhu et al., 2014). The application of both equations in the investigation period is primarily based on the assumption that biochemical oxygen isotope fractionation during cellulose synthesis is almost constant under different temperatures. However, Sternberg and Ellsworth (2011) proposed a temperature effect on cellulose oxygen isotope enrichment relative to source water, especially at temperatures below $20^{\circ} \mathrm{C}$. Accordingly, isotopic enrichment would increase with decreased temperature and the mean of increased enrichment between 4 and $15{ }^{\circ} \mathrm{C}$ is about $2 \%$ (Sternberg and Ellsworth, 2011). This value is, however, derived by summarizing various field studies under different analytical conditions and has not been further confirmed by the latest modern calibration data set from sites in southern Patagonia (Mayr et al., 2013), which shows no apparent effect of host water temperature on the fractionation between aquatic cellulose and host waters.

Samples with sufficient moss cellulose are much less than those providing sufficient moss $\mathrm{OM}$ and residue cellulose. Due to the potential of contamination, the quality of reconstructed $\delta^{18} \mathrm{O}_{\mathrm{lw}}$ values from moss $\mathrm{OM}$ and residue cellulose needs to be critically evaluated (Zhu et al., 2014). For this reason, we have compared the $\delta^{18} \mathrm{O}_{\mathrm{lw}}$ values reconstructed from moss $\mathrm{OM}$ and residue cellulose with those from moss cellulose by using the approach suggested by Zhu et al. (2014).

The effect of ocean water $\delta^{18} \mathrm{O}$ changes on the isotopic composition of meteoric water during the last glacial- interglacial transition had to be accounted for. Thus, reconstructed ocean water $\delta^{18} \mathrm{O}$ values (Lea et al., 2002) were used to correct the effect of ocean water changes on the Laguna Potrok Aike lake water isotopic composition. The data of Lea et al. (2002) were interpolated with a cubic spline function and subtracted from the reconstructed $\delta^{18} \mathrm{O}_{\mathrm{lw}}$ values (Mayr et al., 2013). In the following, the reconstructed $\delta^{18} \mathrm{O}_{\mathrm{lw}}$ corrected for changes in ocean water $\delta^{18} \mathrm{O}$ is denoted as $\delta^{18} \mathrm{O}_{\mathrm{lw}-\text { corr }}$.

\section{Results}

The dry weight of subfossil aquatic moss remains in sediment samples $\left(\sim 10 \mathrm{~cm}^{3}\right)$ varied from complete absence to more than $100 \mathrm{mg}$ (Fig. 4). This large range expresses the variability of moss burial rate within the sedimentary record likely controlled by the abundance of moss habitats in the lake, the vicinity of these habitats to the coring location, the sedimentation rate and the redistribution processes by lake-internal currents. The occurrence of moss organic matter is more discontinuous in lithological unit $\mathrm{C}-1$ than in unit B. Moreover, a trend of reduced moss remains in the sediments towards younger sections, particularly above $16 \mathrm{~m}$ (cd), was observed. The $\mathrm{C} / \mathrm{O}$ ratios of subfossil bulk moss $\mathrm{OM}$, moss cellulose and residue cellulose have mean values of $1.17( \pm 0.05, n=362), 0.88( \pm 0.02, n=144)$ and 0.90 $( \pm 0.02, n=185)$, respectively. These values are consistent with the mean value of 1.17 determined for bulk OM of modern aquatic moss samples and the stoichiometrically expected C / O ratio of 0.90 for cellulose (Wissel et al., 2008; Zhu et al., 2014), which confirms the purity of extracted cellulose and good preservation of moss remains in Laguna Potrok Aike sediments.

The $\delta^{18} \mathrm{O}$ values range from 22.1 to $25.4 \%$ o for bulk moss OM, from 22.8 to $26.7 \%$ o for moss cellulose and from 23.2 to $26.9 \%$ or residue cellulose (Fig. 5). The $\delta^{18} \mathrm{O}$ values are generally more ${ }^{18} \mathrm{O}$-enriched for samples in lithological unit $\mathrm{B}$ than for those in unit $\mathrm{C}-1$. The ${ }^{18} \mathrm{O}$ enrichment in unit $\mathrm{B}$ is more pronounced with up to $2.5 \%$ o for both cellulose fractions than with around $1 \%$ for bulk moss OM. A $\delta^{18} \mathrm{O}$ increase occurs in the transition between the two lithological units within a composite depth range from 22 to $16 \mathrm{~m}$ (cd). Between 30 and $22 \mathrm{~m}(\mathrm{~cd})$ and between 16 and $10 \mathrm{~m}(\mathrm{~cd})$, no general trend is observed for the $\delta^{18} \mathrm{O}$ values of all three fractions, but short-term fluctuations of up to $2 \%$ occur (Fig. 5). The amount of moss material preserved in each sample had no effect on the observed $\delta^{18} \mathrm{O}$ of moss OM (Fig. 6) and any bias due to material availability can thus be excluded. The $\delta^{18} \mathrm{O}$ values of samples from mass movement deposits and volcanic tephra layers are similar to those from the pelagic sediment sections and thus confirm their same lake-internal origin. For further interpretations and reconstructions, the samples from mass movement deposits are excluded. 


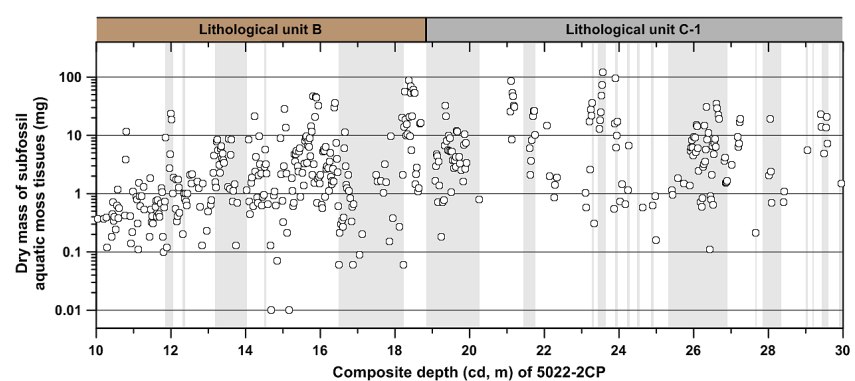

Figure 4. Weighed dry mass of subfossil aquatic moss remains hand-picked from sediment samples within the investigated composite depth range of 5022-2CP of Laguna Potrok Aike. Vertical grey bars represent mass movement deposits and volcanic ash layers. Two lithological units (see text for details) occurring in the investigating depth range are shown at the top of the figure. Note that the $y$ axis is in log scale.

Quality assessment shows that $\delta^{18} \mathrm{O}_{\mathrm{lw}-\text { corr }}$ values inferred from moss $\mathrm{OM}$ and residue cellulose are commonly parallel to the one-to-one moss cellulose line (Fig. 7) and thus confirm the validity of these two fractions for lake water inferences (Zhu et al., 2014). Nevertheless, some samples from lithological unit $\mathrm{C}-1$ show around $1 \%$ more positive $\delta^{18} \mathrm{O}_{\mathrm{lw}-\text { corr }}$ values inferred from bulk moss OM compared to the moss cellulose reference line $(1: 1)$, while more positive $\delta^{18} \mathrm{O}_{\mathrm{lw} \text {-corr }}$ values inferred from residue cellulose are found for a couple of samples from lithological unit B. In terms of $\delta^{13} \mathrm{C}$ values, bulk moss OM generally follows the moss cellulose reference line with an almost constant depletion. However, a marked bias towards more ${ }^{13} \mathrm{C}$-enriched values is observed for the samples of residue cellulose from lithological unit B, which indicates the presence of the remains of aquatic vascular plants in the residue fraction. According to Fig. 7 and Zhu et al. (2014), the observed positive $\delta^{13} \mathrm{C}$ bias range of $2-4 \%$ o suggests a $10-20 \%$ contribution of aquatic vascular plants to the residue fraction, which results, however, only in a positive $\delta^{18} \mathrm{O}$ bias of less than $0.2 \%$, which is well within the analytical uncertainty. Therefore, it is reliable to use the residue cellulose for an auxiliary $\delta^{18} \mathrm{O}_{\mathrm{lw}}$ reconstruction in the present study.

A composite $\delta^{18} \mathrm{O}_{\mathrm{lw}-\text { corr }}$ record based on aquatic moss shoots is constructed by the combination of bulk moss OM and moss cellulose applying moving-average smoothing with a 500-year window (Fig. 8). The composite $\delta^{18} \mathrm{O}_{\mathrm{lw} \text {-corr }}$ record documents a mean $\delta^{18} \mathrm{O}_{\mathrm{lw} \text {-corr value of ca. }-6.5 \% \text { o }}$ between 26000 and $21000 \mathrm{cal}$ BP (Fig. 8). Subsequently, a $\delta^{18} \mathrm{O}_{\mathrm{lw}-\text { corr }}$ decrease of ca. $1 \%$ occurred between 21000 and $17600 \mathrm{cal} \mathrm{BP}$ and the minimum of the complete record of $-7.5 \%$ was reached. From 17600 to $12800 \mathrm{cal} \mathrm{BP \text {, }}$ $\delta^{18} \mathrm{O}_{\mathrm{lw}-\text { corr }}$ strongly increased by nearly $3 \%$ interrupted by a millennial period with declining values of up to ca. $0.7 \%$ beginning at around $15600 \mathrm{cal}$ BP. Afterwards, the $\delta^{18} \mathrm{O}_{\mathrm{lw}-\text { corr }}$ values appeared to be subjected to millennial

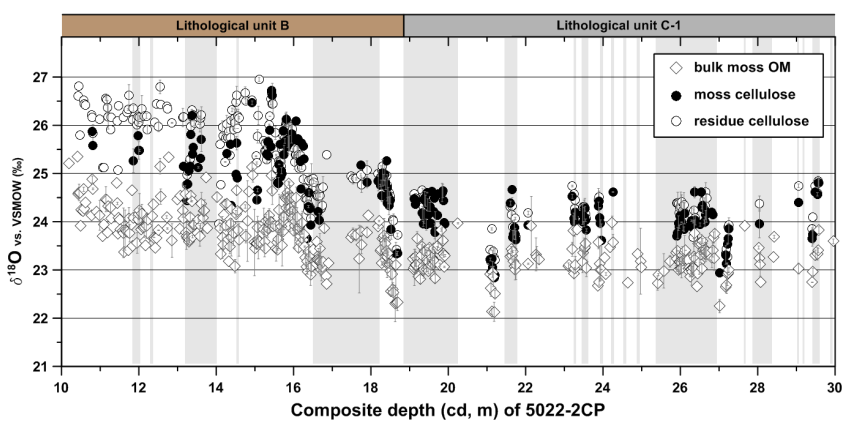

Figure 5. $\delta^{18} \mathrm{O}$ values of all measured samples within the investigated composite depth range of 5022-2CP of Laguna Potrok Aike. Bulk aquatic moss organic matter $(\mathrm{OM})$ is represented by open diamonds, aquatic moss cellulose by closed circles and residue cellulose by open circles. Standard deviations are shown as bars. Vertical grey bars represent mass movement sediment sections and volcanic ash layers. Two lithological units (see text for details) occurring in the investigating depth range are shown at the top of the figure.

scale fluctuations and reached ultimately close to $-3 \%$ in the early Holocene, similar to the present-day values (Fig. 8).

\section{Discussion}

\subsection{Factors controlling lake water $\delta^{18} \mathrm{O}$ of Laguna Potrok Aike}

Variations in $\delta^{18} \mathrm{O}_{\mathrm{lw}}$ are controlled by changes in the isotope composition of input waters (precipitation, surface inflow and groundwater inflow) and changes in the magnitude of subsequent evaporative ${ }^{18} \mathrm{O}$ enrichment (Edwards et al., 2004). It has been found that long-term temporal isotopic variation in precipitation at middle and high latitudes closely follows long-term changes in mean annual air temperature (Rozanski et al., 1992; Teranes and McKenzie, 2001; Darling et al., 2005). Other than temperature change, $\delta^{18} \mathrm{O}$ variations of precipitation can, however, also arise from changes in the direction of air masses bringing moisture to southern Patagonia. Precipitation brought from easterly directions is more enriched in heavy isotopes than those brought by westerly winds. The mean $\delta^{18} \mathrm{O}_{\mathrm{p}}$ of the former and the latter is -8 and $-15 \%$, respectively (Mayr et al., 2007). Thus, within a longer period with increasing air temperature and more frequent easterlies, the $\delta^{18} \mathrm{O}_{\mathrm{p}}$ and, in turn, $\delta^{18} \mathrm{O}$ of inflow and $\delta^{18} \mathrm{O}_{\mathrm{lw}}$ could shift to more positive values. In addition, $\delta^{18} \mathrm{O}_{\mathrm{lw}}$ of lakes in semi-arid southern Patagonia are subjected to strong modification by evaporation, based on the fact that dry, extremely windy and highly evaporative conditions dominate the leeward side of the southern Andes (Garreaud et al., 2013). Today, the mean $\delta^{18} \mathrm{O}$ of inflow (precipitation and groundwater) of Laguna Potrok Aike is around $-13 \%$, while $\delta^{18} \mathrm{O}_{\mathrm{lw}}$ values have a range between -3 and 


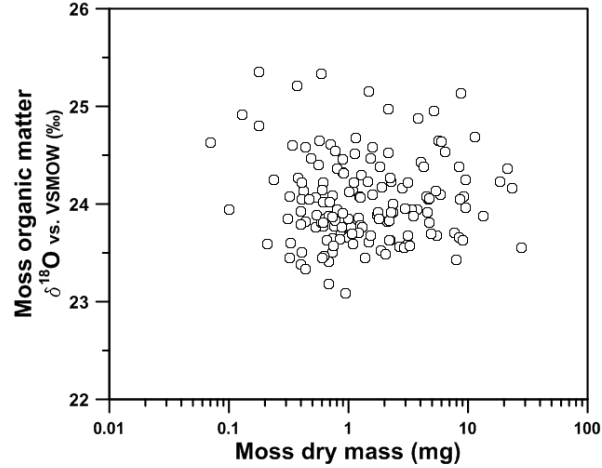

Figure 6. Relationship between dry mass of hand-picked Drepanocladus perplicatus and $\delta^{18} \mathrm{O}$ values of moss organic matter for samples within the composite depth between 10 and $16 \mathrm{~m}$. Note that the $x$ axis is in log scale.

$-4 \%$ (Mayr et al., 2007), indicating high evaporative ${ }^{18} \mathrm{O}$ enrichment of more than $9 \%$ relative to meteoric waters.

In general, the degree of ${ }^{18} \mathrm{O}$ enrichment in through-flow lakes at a hydrological and isotopic steady state is a function of the hydrologic balance, i.e. the ratio of evaporation to inflow (E/I) and relative humidity (Gat, 2010). Accordingly, low relative humidity and high $\mathrm{E} / \mathrm{I}$, as exemplified by increased evaporation and reduced inflow, can cause strong ${ }^{18} \mathrm{O}$ enrichment of lake water. However, under non-steadystate conditions a similar effect could also be induced by a marked increase of the lake water residence time as a result of reduced outflow rates. Presently, relative humidity at Laguna Potrok Aike has an annual average of about $65 \%$ (Ohlendorf et al., 2013) and the calculated E / I based on isotope modelling is around 0.6 (Mayr et al., 2007). Any substantial changes in factors controlling evaporation and relative humidity as well as lake water residence time and isotopic composition of meteoric water during the glacial and the last deglaciation would play a significant role in determining $\delta^{18} \mathrm{O}_{\mathrm{lw}}$ values of Laguna Potrok Aike.

\section{$5.2 \delta^{18} \mathrm{O}_{\mathrm{lw}-\mathrm{corr}}$ of the full glacial (26000-21 000 cal BP)}

Understanding the initial $\delta^{18} \mathrm{O}_{\mathrm{lw}-\text { corr }}$ under the full glacial conditions is crucial for the interpretation of the entire record. The overall amplitude observed for $\delta^{18} \mathrm{O}_{\mathrm{lw}-\text { corr }}$ is about $3.5 \%$ (Fig. 8). This amplitude is smaller than probably expected for the last glacial-interglacial transition with dramatic changes in climatic conditions. $\delta^{18} \mathrm{O}_{\mathrm{lw}-\text { corr }}$ of the glacial period (26000-21 $000 \mathrm{cal} \mathrm{BP})$ seems to be unexpectedly enriched compared to the modern system under strong evaporation conditions (Mayr et al., 2007). Zhu et al. (2014) showed that the $\delta^{18} \mathrm{O}_{\mathrm{lw}}$ values reconstructed from aquatic moss shoots are not affected by decomposition effects, which potentially could mask the original signal. To account for the glacial $\delta^{18} \mathrm{O}_{\mathrm{lw}-\mathrm{corr}}$, which is more enriched than expected,
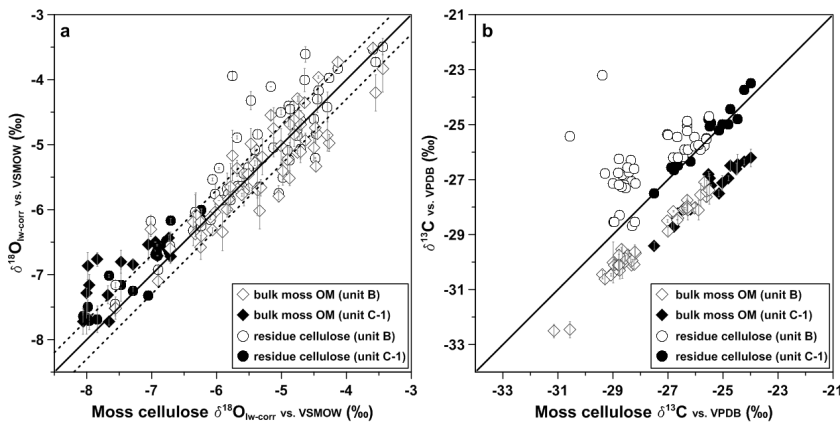

Figure 7. (a) Reconstructed lake-water $\delta^{18} \mathrm{O}\left(\delta^{18} \mathrm{O}_{\mathrm{lw}-\text { corr }}\right)$ from bulk aquatic moss organic matter (OM) (diamonds) and residue cellulose (circles) in relation to $\delta^{18} \mathrm{O}_{\mathrm{lw}-\text { corr values reconstructed }}$ from aquatic moss cellulose. Samples from the sediment sections of mass movement deposits and tephra layers are excluded. Samples from lithological unit B and C-1 are shown in open and closed symbols, respectively. The one-to-one line of $\delta^{18} \mathrm{O}_{\mathrm{lw}-\text { corr values }}$ reconstructed from aquatic moss cellulose is presented as a black line. (b) Same as (a), but for $\delta^{13} \mathrm{C}$ values. The lower and upper limits of the one-to-one line in (a) are presented as dashed lines according to the standard error of regression for modern calibration data set (Zhu et al., 2014). Standard deviations of individual values are given as bars in (a) and (b).

two alternative scenarios with either (i) a markedly ${ }^{18} \mathrm{O}$ depleted inflow or (ii) a moderately changed $\delta^{18} \mathrm{O}$ inflow compared to modern inflow into Laguna Potrok Aike are discussed.

\section{$\delta^{18} \mathrm{O}$ of meteoric water and groundwater markedly lower than present}

All estimates of regional temperatures in southern Patagonia indicate a pronounced decrease during the last glacial. Alkenone-derived sea-surface temperatures (SST) from marine sediment cores off the Chilean coast (Fig. 9f) indicate lower SSTs by ca. $6^{\circ} \mathrm{C}$ for the last glacial relative to the present (Lamy et al., 2007; Caniupan et al., 2011). For the South American continent, lower air temperatures by 8 $10^{\circ} \mathrm{C}$ during the LGM than today have been inferred from coupled ocean-atmosphere simulations (Rojas et al., 2009). Furthermore, Trombotto (2002) suggested a lowering of the mean annual air temperature of at least $14^{\circ} \mathrm{C}$ in southern Patagonia during the LGM based on the presence of icewedge casts.

As discussed in Sect. 5.1, $\delta^{18} \mathrm{O}_{\mathrm{p}}$ is positively correlated with surface air temperature. A mean spatial gradient of $\delta^{18} \mathrm{O}_{\mathrm{p}}$ with surface air temperature of $0.53 \%$ o per ${ }^{\circ} \mathrm{C}$ (Gourcy et al., 2005) or $0.58 \%$ o per ${ }^{\circ} \mathrm{C}$ (Rozanski et al., 1993) has been reported. On the temporal scale, an average $\delta^{18} \mathrm{O}_{\mathrm{p}}$ temperature coefficient of about $0.6 \%$ per ${ }^{\circ} \mathrm{C}$ is observed at mid- and high latitudes (Rozanski et al., 1992). According to this relation, distinctly lowered temperatures would cause a strong ${ }^{18} \mathrm{O}$ depletion of precipitation of the order of $6 \% 0$ 


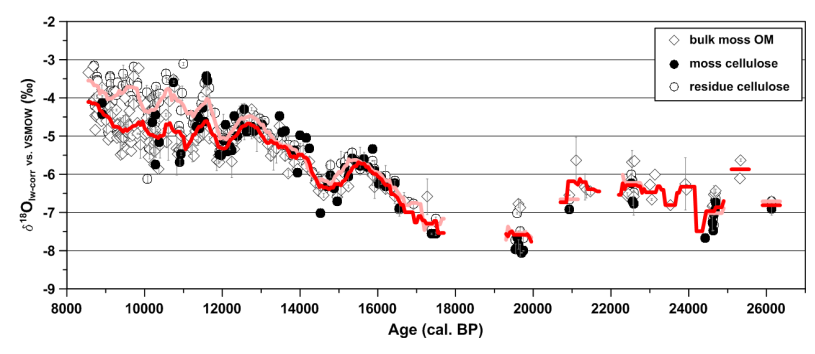

Figure 8. Isotopic record of reconstructed lake-water $\delta^{18} \mathrm{O}$ $\left(\delta^{18} \mathrm{O}_{\mathrm{lw}-\text { corr }}\right)$ from bulk aquatic moss organic matter (OM), aquatic moss cellulose and residue cellulose during the last glacialinterglacial transition period. Samples from the sediment sections of mass movement deposits and tephra layers are excluded. Coloured lines represent the moving average smoothing using a 500-year window (red: smoothing of average $\delta^{18} \mathrm{O}_{\mathrm{lw}-\text { corr }}$ of composite aquatic moss record combining moss $\mathrm{OM}$ with moss cellulose; pale red: smoothing of $\delta^{18} \mathrm{O}_{\mathrm{lw}-\text { corr }}$ of residue cellulose). Discontinuity prior to $17600 \mathrm{cal} \mathrm{BP}$ is caused by insufficient moss material.

in southern Patagonia during the full glacial compared to the present. If the groundwater flowing into Laguna Potrok Aike is mainly recharged by regional precipitation, the strong ${ }^{18} \mathrm{O}$ depletion of glacial precipitation would also have a direct impact on the $\delta^{18} \mathrm{O}$ of inflow. Under these circumstances, $\delta^{18} \mathrm{O}$ of surface and subsurface inflow into Laguna Potrok Aike during the full glacial would be about $-19 \%$ (present value: $-13 \%$ ) assuming that the balance of precipitation from the Pacific and Atlantic was similar to today. This large ${ }^{18} \mathrm{O}$ depletion of inflow would result in an ${ }^{18} \mathrm{O}$ enrichment of about $12 \%$ o between $\delta^{18} \mathrm{O}_{\mathrm{lw}-\text { corr }}\left(-6.5 \%\right.$ ) recorded and $\delta^{18} \mathrm{O}$ of inflow $(-19 \%$ ) during the full glacial compared to a modern ${ }^{18} \mathrm{O}$ enrichment of about $9 \%$ (Mayr et al., 2007).

Today, the climate in the southeastern Patagonian steppe is characterized by strong westerly winds which are adiabatically warmed and dried while passing the Andes, leading to semi-arid and highly evaporative conditions in eastern Patagonia (Garreaud et al., 2013) that explain the modern ${ }^{18} \mathrm{O}$ enrichment of lake water. Enrichment during the full glacial might also have been caused by evaporation induced by a similar föhn-wind effect. It might have been strengthened by the thick Patagonian Ice Sheet covering the southern Andes, which might have increased adiabatic warming and drying of subsiding air masses coming from westerly directions. This föhn-wind effect could be very pronounced in a cold and dry environment during the glacial, which is corroborated by palynological studies of Laguna Potrok Aike sediments (Recasens et al., 2012). At Lake Hoare in the modern McMurdo Dry Valley of Antarctica, strong and dry regional föhn winds heat adiabatically by about $20^{\circ} \mathrm{C}$ (from -30 to $-10^{\circ} \mathrm{C}$ ) upon their descent from the surrounding ice plateau, even in sunless austral winters (Clow et al., 1988). At a mean annual temperature of less than $-15^{\circ} \mathrm{C}$ in the Dry Valley region, relative humidity averages to only 0.54 and the annual sublimation (ablation) rate of surface ice of lakes reaches about $300 \mathrm{~mm}$ (Clow et al., 1988; Chinn, 1993). In a similar way, strong and extremely dry downslope föhn winds passing the ice-covered southern Andes could have resulted in higher-than-present evaporation and sublimation rates during the glacial. Thus, isotopic enrichment of lake water during the full glacial could have been stronger than expected.

This interpretation is largely based on the predominance of the SHW at the latitude of Laguna Potrok Aike $\left(52^{\circ} \mathrm{S}\right)$ during the glacial. The Patagonian Ice Sheet covering the southern Andes from 38 to $56^{\circ} \mathrm{S}$ during the LGM (Glasser et al., 2008) implies the existence of westerly winds within this latitudinal belt, because a positive mass balance of modern glaciers in the southern Andes is favoured by low summer temperature and high precipitation, and the latter is, in turn, largely related to the westerly winds from the Pacific (Schneider et al., 2003). In fact, palaeoclimate studies from sites between 30 and $45^{\circ} \mathrm{S}$ in southwestern South America have implied much higher precipitation during the glacial compared to the present (e.g. Heusser, 1989; Lamy et al., 1999; Moreno et al., 1999; Valero-Garcés et al., 2005). Taken together, that would imply a broader latitudinal extension of the SHW belt during the glacial compared to the present.

\section{(ii) Moderate change in $\delta^{18} \mathrm{O}$ of source water compared to the present}

If the SHW were located in a more equatorward position (Williams and Bryan, 2006), the balance between westerly and easterly winds would shift towards more easterly winds, which consequently could have dominated in southern Patagonia during the glacial. Assuming almost $100 \%$ precipitation moisture from the Atlantic, $\delta^{18} \mathrm{O}_{\mathrm{p}}$ could be roughly estimated for about $-14 \%$ (see Sect. 5.1: present value easterlies $-8 \%$ ). In this case, $\delta^{18} \mathrm{O}$ of inflow into Laguna Potrok Aike would be more positive than the estimation $(-19 \%)$ in scenario (i) and the magnitude of ${ }^{18} \mathrm{O}$ enrichment would be smaller accordingly.

If the glacial temperature in southern Patagonia was lowered by more than $10^{\circ} \mathrm{C}$ (cf. discussion in scenario (i)), the local mean annual temperature at Laguna Potrok Aike would be lower than $-3{ }^{\circ} \mathrm{C}$ during the glacial and the formation of permafrost would be fostered. The occurrence of a relict sand wedge dated to $35 \pm 3 \mathrm{ka}$ in the Laguna Potrok Aike catchment area (Kliem et al., 2013a) indeed suggests permafrost conditions during the glacial around the lake. Deep permafrost during the glacial would have major impacts on the hydrological and isotopic water balance of Laguna Potrok Aike. Groundwater recharge from meteoric water may have been strongly reduced due to impervious permafrost layers. Hence, any isotopic change in the precipitation may not have been fully transmitted into the groundwater. Decreased precipitation and accordingly limited surface and subsurface inflows during the full glacial would also generally make a smaller contribution to the lake water budget than today. Thus, the expected large negative shift in $\delta^{18} \mathrm{O}$ of inflow, as 
discussed in scenario (i), may not have occurred. In addition, deep permafrost could have largely prohibited the exchange between the groundwater and the lake water body (subsurface in- and outflow), thus converting Laguna Potrok Aike into a closed lake system with extremely prolonged lake water residence time under non-overflow conditions. Under these circumstances, even small evaporative isotopic enrichment effects could sum up to considerable cumulative ${ }^{18} \mathrm{O}$ enrichment of lake water.

In the absence of any further knowledge on key parameters determining the isotopic water balance of Laguna Potrok Aike, especially relative humidity and isotopic composition of atmospheric moisture and considering the occurrence of permafrost, it seems more likely that the $\delta^{18} \mathrm{O}$ value of source water was not as negative as discussed in scenario (i), mainly due to a shift in the moisture source area, and that prolonged lake water residence time led to further cumulative ${ }^{18} \mathrm{O}$ enrichment of lake water. Scenario (ii) is thus preferred for explaining the observed glacial $\delta^{18} \mathrm{O}_{\mathrm{lw}-\text { corr }}$ values. Accordingly, the factor of SHW wind-driven evaporation would not be a determinant for the lake water balance, which is consistent with the hypothesis of an equatorward shift of 7$10^{\circ}$ latitude of the SHW belt during the LGM (Toggweiler et al., 2006). However, the changes in strength and latitudinal position of the SHW during the LGM relative to today are still in an open debate, as a consequence of uncertainties in modelling results (Chavaillaz et al., 2013; Pollock and Bush, 2013; Rojas, 2013; Sime et al., 2013) and ambiguities in proxy interpretations (Kohfeld et al., 2013).

Besides several other important factors, this interpretation is conceptually based on the modern spatial temperature$\delta^{18} \mathrm{O}$-precipitation relation of the mid-latitudes (Kohn and Welker, 2005) and its stationarity in time to explain temporal $\delta^{18} \mathrm{O}$ variations. Several studies with isotope-enabled general circulation models (GCM) confirm this principle (Schmidt et al, 2007), even for the large climatic changes during the last glacial-interglacial cycle (Jouzel et al., 2000, 2003; Risi et al., 2010). In these studies, comparison of modern and LGM scenarios suggest temporal slopes similar to the spatial slopes with differences attributed, for example, to changes in seasonal temperatures (Lee et al., 2008) or to model forcings (Risi et al., 2010). Interestingly, in their GCM study, Jouzel et al. (2000) also derived a difference of about $3 \%$ o for $\delta^{18} \mathrm{O}$ in precipitation between their modern and LGM zonal means at $52^{\circ} \mathrm{S}$. An alteration in $\delta^{18} \mathrm{O}$ precipitation of this order of magnitude would be consistent with the glacial to early Holocene change in $\delta^{18} \mathrm{O}_{\mathrm{lw}-\text { corr }}$ observed in our study at Laguna Potrok Aike and might thus explain the change in lake water isotopic composition during deglaciation. However, such a comparably small LGM to modern change in $\delta^{18} \mathrm{O}$ precipitation would evidently contradict the stationarity of the temperature- $\delta^{18} \mathrm{O}$-precipitation relation in time or the temperature change reconstructed for these latitudes in southern South America (e.g. Rojas et al., 2009). For the moment, more evidence seems to be in support of a tempo-

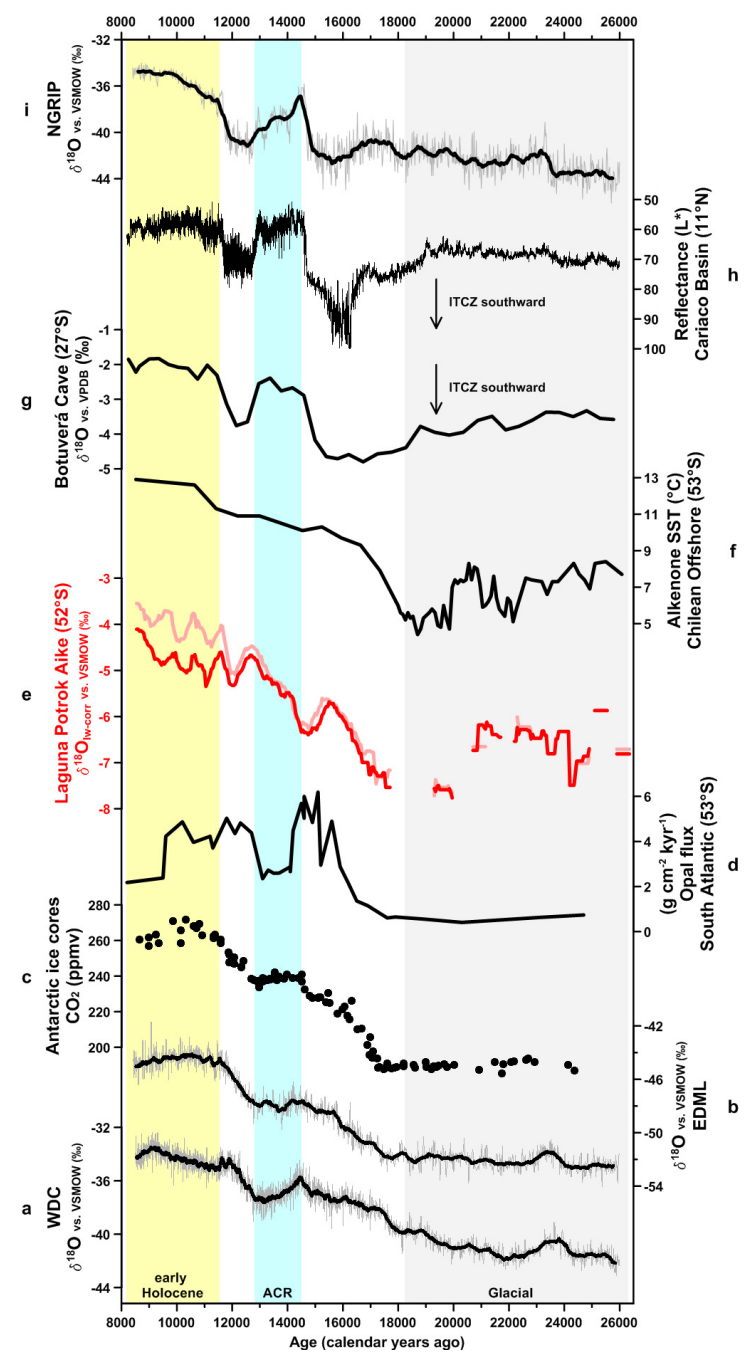

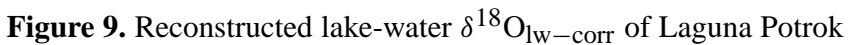
Aike in comparison to global proxy records. (a) $\delta^{18} \mathrm{O}$ record from the WDC in West Antarctica (WAIS Divide Project Members, 2013). (b) $\delta^{18} \mathrm{O}$ record from EDML of East Antarctica (EPICA Community Members, 2006). (c) $\mathrm{CO}_{2}$ concentration from Antarctic ice cores (Schmitt et al., 2012). (d) Opal flux of TN057-13-4PC $\left(53^{\circ} \mathrm{S}\right)$ in the southern Atlantic (Anderson et al., 2009). (e) Reconstructed lake-water $\delta^{18} \mathrm{O}\left(\delta^{18} \mathrm{O}_{\mathrm{lw}-\text { corr }}\right)$ of Laguna Potrok Aike in this study, smoothed by a 500-year window (red: smoothing of average $\delta^{18} \mathrm{O}_{\mathrm{lw}-\text { corr }}$ of composite aquatic moss record combining moss cellulose with moss OM; pale red: smoothing of $\delta^{18} \mathrm{O}_{\mathrm{lw}-\text { corr }}$ of residue cellulose). The ocean water effect during the LGM and deglaciation has been corrected according to Lea et al. (2002). (f) Alkenone-derived SST record from the offshore core MD07$3128\left(53^{\circ} \mathrm{S}\right)$ (Caniupán et al., 2011). (g) $\delta^{18} \mathrm{O}$ record of Botuverá Cave $\left(27^{\circ} \mathrm{S}\right)$ in southern Brazil (indicator of the ITCZ position) (Wang et al., 2007). (h) Sediment total reflectance from Cariaco Basin (indicator of the ITCZ position) (Deplazes et al., 2013). Note the reverse scale of the $y$ axis. (i) $\delta^{18} \mathrm{O}$ record of NGRIP on GICC05 timescale (Anderson et al., 2006; Rasmussen et al., 2006). ACR: Antarctic Cold Reversal. 
rally stationary local $T /{ }^{18} \mathrm{O} \%$ gradient in precipitation. Irrespective of that, palaeogeographical changes (e.g. distance to the coast), changes in seasonality or changes in atmospheric circulation patterns like in our scenario (ii) could induce additional $\delta^{18} \mathrm{O}$ source value effects that might mimic a non-stationarity of the $T /{ }^{18} \mathrm{O} \%$ gradient (Sturm et al., 2010). Our study enables and hopefully stimulates further studies with regard to the interpretation of $\delta^{18} \mathrm{O}$ changes in climate reconstructions and the relevance of local temperature, changes in seasonality and synoptic atmospheric circulation changes.

\subsection{Evolution of $\delta^{18} \mathrm{O}_{\mathrm{lw}-\text { corr }}$ and deglaciation history since 21000 cal BP}

Between 21000 and $19500 \mathrm{cal} \mathrm{BP}, \delta^{18} \mathrm{O}_{\mathrm{lw}-\mathrm{corr}}$ decreased from the main glacial level of about $-6 \%$ owards a level of around $-7.5 \%$ that was probably held until $17600 \mathrm{cal} \mathrm{BP}$ (Fig. 9e). This depletion by ca. $1.5 \%$ is large concerning the total amplitude of $3.5 \%$ for the entire record. Despite the discontinuous record for this time interval, the $\delta^{18} \mathrm{O}_{\mathrm{lw}-\text { corr }}$ of around $-7.5 \%$ recorded around 19000 and at $17600 \mathrm{cal} \mathrm{BP}$ implies less evaporative enrichment or more ${ }^{18} \mathrm{O}$-depleted surface inflow from ice or snow melt during this period. This is in line with the occurrence of exposed lacustrine sediments testifying an overflow situation for Laguna Potrok Aike at around $17 \mathrm{ka}$ by OSL dating (Kliem et al., 2013a). The longterm SST cooling trend from $\sim 25000$ to $19000 \mathrm{yr} \mathrm{BP}$ from a marine site (MD07-3128, $53^{\circ} \mathrm{S}$ ) close to the Patagonian Ice Sheet has been interpreted as a locally enhanced SST cooling induced by the supply of large amounts of meltwater (Caniupán et al., 2011; Fig. 9f). The timing of a large SST cooling at around $21 \mathrm{kyr} \mathrm{BP} \mathrm{(Fig.} \mathrm{9f)} \mathrm{is} \mathrm{consistent} \mathrm{with}$ the beginning of the distinct depletion of $\delta^{18} \mathrm{O}_{\mathrm{lw}-\text { corr }}$ in Laguna Potrok Aike. About two millennia prior to the onset of the last deglaciation, the Intertropical Convergence Zone (ITCZ) also began to shift southward, as indicated by intensified South America summer monsoon precipitation in southern Brazil and diminished rain falls in the drain regions of the Cariaco Basin (Wang et al., 2007; Deplazes et al., 2013; Fig. 9g and h).

A marked and sustained two-step increase of $\delta^{18} \mathrm{O}_{\mathrm{lw}-\mathrm{corr}}$ started from $17600 \mathrm{cal}$ BP onwards (Fig. 9e) and lasted until $12800 \mathrm{cal}$ BP with a millennial recession phase beginning at around $15600 \mathrm{cal}$ BP. The first increase lasted until $15600 \mathrm{cal} \mathrm{BP}$ and signifies the onset of the last deglaciation in the Patagonian steppe. This increase in $\delta^{18} \mathrm{O}_{\mathrm{lw}-\text { corr }}$ was not included in an earlier data set (Mayr et al., 2013), but is clearly shown in our new data set, which has also an improved temporal resolution and lower analytical uncertainty. The initial rise of $\delta^{18} \mathrm{O}_{\mathrm{lw}-\mathrm{corr}}$ from around $17600 \mathrm{cal} \mathrm{BP}$ occurred simultaneously with a rapid increase of lacustrine primary productivity in Laguna Potrok Aike reported by Hahn et al. (2013) and Zhu et al. (2013). This development at Laguna Potrok Aike is concurrent with increasing Antarctic temperatures (Fig. 9a and b), rising atmospheric $\mathrm{CO}_{2}$ concentrations (Fig. 9c), an increased upwelling in the Southern Ocean (Fig. 9d), warming off the coast of southern Chile (Fig. 9f) and a large southward displacement of the ITCZ (Fig. 9g and h). Moreover, glacier fluctuations in southern Patagonia also suggest rapid and widespread glacier retreat in the Andes around 18300-17500 cal BP (e.g. McCulloch et al., 2005; Sagredo et al., 2011), coinciding with deglacial warming.

Climatic warming alone has several effects on the isotopic water balance of Laguna Potrok Aike that altogether would certainly induce a cumulative rise in $\delta^{18} \mathrm{O}_{\mathrm{lw}}$ during the initial phase of the last deglaciation. Firstly, increasing air temperature will cause an equivalent change in the isotopic composition of meteoric water towards more enriched isotopic values independent of its origin from the Pacific or Atlantic. For precipitation moisture from the Pacific, this effect could be reinforced by a diminishing isotopic rainshadow effect due to the receding Patagonian Ice Sheet. Secondly, rising air temperatures would result in a local moisture deficit and strengthen temperature-driven evaporation leading to enhanced ${ }^{18} \mathrm{O}$ enrichment of lake water. Thirdly, thawing permafrost would facilitate higher groundwater recharge from regional precipitation. The $\delta^{18} \mathrm{O}$ of groundwater then would be closely coupled with $\delta^{18} \mathrm{O}_{\mathrm{p}}$ and affected by climate warming on the long-term scale. Considering the concept of E / I, the lake is in a non-steady-state condition during this phase induced by massive palaeogeographic and palaeoenvironmental changes, where, according to all considerations, increasing surface air temperature must be an important driver. It might thus be argued that the first deglacial rise in $\delta^{18} \mathrm{O}_{\mathrm{lw} \text {-corr lasting two millennia was mainly caused }}$ by rapid deglacial warming in southern Patagonia and the southern high latitudes (Pendall et al., 2001; Caniupán et al., 2011; Fig. 9a, b and f). Moreover, more ${ }^{18} \mathrm{O}$-enriched moisture from the Atlantic could be brought into southern Patagonia due to sea-surface warming and a poleward-retreating sea-ice front in the South Atlantic (Gersonde et al., 2005; Allen et al, 2011), as the westerly winds were probably weak. By contrast, according to Toggweiler et al. (2006) and Denton et al. (2010), the SHW shifted rapidly poleward at the onset of the last deglaciation. Such a rapid onset of strong westerly winds would induce a change in the moisture source area and strong evaporation from the lake water surface with strong evaporative isotopic enrichment that would explain the rising $\delta^{18} \mathrm{O}_{\mathrm{lw}-\text { corr }}$ as well. However, previous studies have related the massive abundance of pollen from the aquatic taxon Myriophyllum (Wille et al., 2007) and high lacustrine primary productivity (Hahn et al., 2013; Zhu et al., 2013) during the initial phase of the last deglaciation to relatively calm wind conditions favouring the flowering of Myriophyllum and algal blooms in warmer surface waters and seasonal stratification.

At around $15600 \mathrm{cal} \mathrm{BP}$, the overall increase in $\delta^{18} \mathrm{O}_{\mathrm{lw}-\mathrm{corr}}$ is reversed during a phase lasting ca. 1000 years 
with declining values. To some extent this period resembles the Antarctic Cold Reversal (ACR), with reduced opal flux in the Southern Ocean and a halt in the increase of atmospheric $\mathrm{CO}_{2}$ concentrations (Fig. 9c and d), but occurs about 1000 years earlier. Since the independent tephra time marker Reclús $R_{1}$ occurring at the end of this phase strongly supports the reliability of the current age-depth model, the decrease in $\delta^{18} \mathrm{O}_{\mathrm{lw}-\text { corr }}$ began at least before 15000 cal BP and cannot be synchronized with the ACR. The decreasing $\delta^{18} \mathrm{O}_{\mathrm{lw}-\text { corr }}$ during this phase could probably be explained by increasing groundwater inflow into Laguna Potrok Aike or by decreasing evaporation together with a change in the moisture source area from the Atlantic to the Pacific. Groundwater through-flow fostered by thawing permafrost and then supplied with ${ }^{18} \mathrm{O}$-depleted ice meltwater from the Andes could have been increased, since $80 \%$ of the ice volume of the Patagonia Ice Sheet was suggested to be lost during the early phase of the last deglaciation (Hulton et al., 2002; Hubbard et al., 2005). Furthermore, large ice-dammed proglacial lakes existed about $100 \mathrm{~km}$ west of Laguna Potrok Aike during this phase (e.g. Sagredo et al., 2011; Solari et al., 2012) and probably provided an additional ${ }^{18} \mathrm{O}$-depleted water source. Alternatively, this period might also represent a change in the dominant driver of the ${ }^{18} \mathrm{O}$ enrichment of lake water. Around that time the rapid climate warming during the initial phase of the last deglaciation is completed and the further rise in SST is much slower (Fig. 9f). Assuming that from now on the SHW progressively increased their influence on the hydrological balance of Laguna Potrok Aike, a decline in the ${ }^{18} \mathrm{O}$ enrichment of lake water could have occurred, as the increasing influence of the SHW during this period could not yet compensate for the lessening of temperature-driven evaporation and concomitant changes in the moisture source value. Only until the SHW exerted their full influence strengthened wind-driven evaporation would result in large evaporative ${ }^{18} \mathrm{O}$ enrichment of lake water and

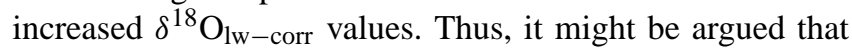
progressively enriched $\delta^{18} \mathrm{O}_{\mathrm{lw}-\text { corr }}$ of Laguna Potrok Aike from about $14600 \mathrm{cal} \mathrm{BP}$ (Fig. 9e) onward is mainly ascribed to intensified westerly winds and only to a lesser extent to the further slow temperature rise. This is consistent with a progressive increase in the intensity of the SHW over the period from the ACR until about $13000 \mathrm{cal} \mathrm{BP}$ and a maximum SHW strength at $52^{\circ} \mathrm{S}$ during the following millennia indicated by Mayr et al. (2013) for the period between 13400 and $11300 \mathrm{cal}$ BP. For the period of the early Holocene, $\delta^{18} \mathrm{O}_{\mathrm{lw}-\text { corr }}$ values reconstructed from residue fraction are ${ }^{18} \mathrm{O}$-enriched by up to $1 \%$ o compared to those inferred from aquatic moss shoots. This ${ }^{18} \mathrm{O}$ enrichment can possibly be attributed to a contamination with terrestrial plant tissues of the residue fraction. Nevertheless, increasing $\delta^{18} \mathrm{O}_{\mathrm{lw}-\mathrm{corr}}$ since the onset of the early Holocene suggests an elevated E / I ratio, coinciding with the timing of the lake level lowering that reached a depth of $-33 \mathrm{~m}$ below the modern one shortly be- fore $6790 \mathrm{cal}$ BP (Haberzettl et al., 2008; Anselmetti et al., 2009; Zolitschka et al. 2013).

Like the patterns of changes in the SHW during the LGM, also the reconstructed development of the SHW during the last deglaciation and the early Holocene based on sites in southern Patagonia remains controversial (see Kilian and Lamy, 2012; Moreno et al., 2012; Villa-Martínez et al., 2012).

\section{Conclusions}

This study presents a high-resolution $\delta^{18} \mathrm{O}_{\mathrm{lw}-\text { corr reconstruc- }}$ tion for Laguna Potrok Aike located in semi-arid southern Patagonia throughout the last glacial-interglacial transition by using purified bulk OM and extracted cellulose of subfossil submerged aquatic mosses. These data provide a unique continental proxy record of the environmental development in the high southern latitudes during this period of fundamental climatic shifts. The temporal evolution of $\delta^{18} \mathrm{O}_{\mathrm{lw}-\text { corr }}$ of Laguna Potrok Aike is largely controlled by changes in $\delta^{18} \mathrm{O}$ of the lake's source water, surface air temperature and evaporative ${ }^{18} \mathrm{O}$ enrichment.

Considering two competing hypotheses, the $\delta^{18} \mathrm{O}_{\mathrm{lw}-\text { corr }}$ record between 26000 and 21000 cal BP is currently best explained by a scenario of weakened glacial SHW compared to the present. With moisture mainly from easterly directions and the occurrence of permafrost during the glacial, the inflow into the lake would not be as depleted as under a strong SHW scenario. Reduced interchange between in- and outflows and generally decreased inflows would have prolonged the lake water residence time. Under these circumstances, higher than expected $\delta^{18} \mathrm{O}_{\mathrm{lw}-\text { corr }}$ during this period could be achieved despite weakened evaporation under glacial conditions. This interpretation is consistent with hypotheses for an equatorward shift of the SHW during the last glacial.

Between 21000 and $17600 \mathrm{cal} \mathrm{BP}$, coinciding with the timing of a reconstructed lake level overflow of Laguna Potrok Aike, a large depletion in $\delta^{18} \mathrm{O}_{\mathrm{lw}-\text { corr }}$ is observed. Low $\delta^{18} \mathrm{O}_{\mathrm{lw}-\text { corr }}$ together with the overflow situation could be linked to an increased proportion of ${ }^{18} \mathrm{O}$-depleted ice or snow meltwater reaching Laguna Potrok Aike via groundwater and surface inflows. Such an early meltwater flow could be caused by an initial amelioration phase preceding the genuine deglaciation.

During the early phase of the last deglaciation from 17600 to $15600 \mathrm{cal} \mathrm{BP}$, the $\delta^{18} \mathrm{O}_{\mathrm{lw}-\mathrm{corr}}$ record shows a distinct increase. Considering the potential influence of strongly increased air temperature, this development of $\delta^{18} \mathrm{O}_{\mathrm{lw}-\text { corr }}$ can be interpreted as rapid climatic warming resulting in enhanced temperature-driven evaporation and cumulatively ${ }^{18} \mathrm{O}$-enriched meteoric water. Thus, an early strengthening of the SHW is not a necessary prerequisite to explain this pattern. Nevertheless, our data would also be in line with a rapid poleward shift of the SHW (Toggweiler et al., 2006) 
immediately after the onset of the last deglaciation, given wind-driven evaporation as the sole driver of increasing $\delta^{18} \mathrm{O}_{\mathrm{lw}-\mathrm{corr}}$ in Laguna Potrok Aike.

The subsequent period from 15600 to 14600 cal BP is characterized by declining $\delta^{18} \mathrm{O}_{\mathrm{lw}-\text { corr }}$ of the Patagonian steppe lake. This period is not equivalent to the ACR, because its onset preceded the ACR by at least 500 years according to the independent tephra time marker. It seems plausible to interpret this decline as the transition from a mainly temperature-driven towards a wind-driven evaporative enrichment of $\delta^{18} \mathrm{O}_{\mathrm{lw}-\mathrm{corr}}$. With the end of the strong temperature rise during the first two millennia and the onset of intensified SHW, $\delta^{18} \mathrm{O}_{\mathrm{lw}-\text { corr }}$ would be initially reduced due to the increased heat export from the continent and the import of depleted moisture from the Pacific.

After $14600 \mathrm{cal} \mathrm{BP}$, the $\delta^{18} \mathrm{O}_{\mathrm{lw} \text {-corr }}$ record resumed its strong increase, indicating that from this point on, at the latest, the intensifying SHW exerted their dominant control on the lake water balance of Laguna Potrok Aike through strengthened wind-driven evaporation. The SHW must have been established at the latitude of Laguna Potrok Aike $\left(52^{\circ} \mathrm{S}\right)$ and increased in strength towards the early Holocene when the maximum was reached.

The overall development of the $\delta^{18} \mathrm{O}_{\mathrm{lw}-\text { corr }}$ record during the last glacial-interglacial transition is consistent with lake level reconstructions describing an overflow situation prior to $17000 \mathrm{cal} \mathrm{BP}$ and a lowering of the lake level during the early Holocene, suggesting the development of a strongly evaporative steppe climate in the Laguna Potrok Aike region since the last deglaciation.

Our interpretation of the $\delta^{18} \mathrm{O}_{\mathrm{lw}-\mathrm{corr}}$ record of Laguna Potrok Aike provides a new view to the highly controversial topic regarding the patterns of changes in the SHW throughout the last glacial-interglacial transition. This demonstrates that the understanding of SHW evolution in the high southern latitudes during this dynamic period is still far away from a consensus.

Acknowledgements. We are indebted to J.-P. Frahm and L. Hedenäs for identification of aquatic mosses. This research used samples provided by the International Continental Scientific Drilling Program (ICDP) in the framework of the Potrok Aike Maar Lake Sediment Archive Drilling Project (PASADO). Funding for drilling was provided by the ICDP, the German Science Foundation (DFG), the Swiss National Funds (SNF), the Natural Sciences and Engineering Research Council of Canada (NSERC), the Swedish Research Council (VR) and the University of Bremen, Germany. The study was funded by grants of the DFG (LU786/7-1,2, MA4235/4-1,2) in the framework of the SPP1006 (ICDP). J. Zhu is very grateful to F. Lehmkuhl (RWTH Aachen University, Germany) for cosupervision of his $\mathrm{PhD}$ thesis. We are grateful to two anonymous reviewers and the editor $\mathrm{H}$. Fischer for their constructive and valuable comments that helped to improve the manuscript substantially.
The service charges for this open access publication have been covered by a Research Centre of the Helmholtz Association.

Edited by: H. Fischer

\section{References}

Allen, C. S., Pike, J., and Pudsey, C. J.: Last glacial-interglacial sea-ice cover in the SW Atlantic and its potential role in global deglaciation, Quaternary Sci. Rev., 30, 2446-2458, 2011.

Anderson, K. K., Svensson, A., Johnsen, S. J., Rasmussen, S. O., Bigler, M., Röthlisberger, R., Ruth, U., Siggaard-Anderson, M.-L., Steffensen, J. P., Dahl-Jensen, D., Vinther, B. M., and Clausen, H. B.: The Greenland Ice Core Chronology 2005, 15$42 \mathrm{ka}$, Part 1: constructing the time scale, Quaternary Sci. Rev., 25, 3246-3257, 2006.

Anderson, R. F., Ali, S., Bradtmiller, L. I., Nielsen, S. H. H., Fleisher, M. Q., Anderson, B. E., and Burckle, L. H.: Winddriven upwelling in the Southern Ocean and the deglacial rise in atmospheric $\mathrm{CO}_{2}$, Science, 323, 1443-1448, 2009.

Anselmetti, F., Ariztegui, D., De Batist, M., Gebhardt, C., Haberzettl, T., Niessen, F., Ohlendorf, C., and Zolitschka, B.: Environmental history of southern Patagonia unravelled by the seismic stratigraphy of Laguna Potrok Aike, Sedimentology, 56, 873-892, 2009.

Ariztegui, D., Gilli, A., Anselmetti, F. S., Goñi, R. A., Belardi, J. B., and Espinosa S.: Lake-level changes in central Patagonia (Argentina): crossing environmental thresholds for Lateglacial and Holocene human occupation, J. Quaternary Sci., 25, 1092-1099, 2010.

Blaauw, M.: Methods and code for "classical" age-modelling of radiocarbon sequences, Quat. Geochronol., 5, 512-518, 2010.

Brand, W. A., Coplen, T. B., Aerts-Bijma, A. T., Böhlke, J. K., Gehre, M., Geilmann, H., Gröning, M., Jansen, H. G., Meijer, H. A., Mroczkowski, S. J., Qi, H., Soergel, K., Stuart-Williams, H., Weise, S. M., and Werner R. A.: Comprehensive inter-laboratory calibration of reference materials for $\delta^{18} \mathrm{O}$ versus VSMOW using various on-line high-temperature conversion techniques, Rapid Commun. Mass. Sp., 23, 999-1019, 2009.

Caniupán, M., Lamy, F., Lange, C. B., Kaiser, J., Arz, H., Kilian, R., Baeza Urrea, O., Aracena, C., Hebbeln, D., Kissel, C., Laj, C., Mollenhauer, G., and Tiedemann, R.: Millennial-scale sea surface temperature and Patagonia Ice Sheet changes off southernmost Chile $\left(53^{\circ} \mathrm{S}\right)$ over the past $\sim 60 \mathrm{kyr}$, Paleoceanography, 26 , PA3221, doi:10.1029/2010PA002049, 2011.

Chavaillaz, Y., Codron, F., and Kageyama, M.: Southern westerlies in LGM and future (RCP4.5) climates, Clim. Past, 9, 517-524, 2013 , http://www.clim-past.net/9/517/2013/.

Chinn, T. J.: Physical hydrology of the Dry Valley lakes, in: Physical and Biogeochemical Processes in Antarctic lakes, Antarctic Research Series, edited by: Friedman, G. W. J. and Friedman, E. I., American Geophysical Union, Washington DC, 1-51, 1993.

Clow, G. D., McKay, C. P., Simmons, G. M., and Wharton, R. A.: Climatological observations and predicted sublimation rates at Lake Hoare, Antarctica, J. Climate, 1, 715-728, 1988. 
Coplen, T. B., Brand, W. A., Gehre, M., Gröning, M., Meijer, H. A. J., Toman, B., and Verkouteren, R. M.: New Guidelines for $\delta^{13} \mathrm{C}$ Measurements, Anal. Chem., 78, 2439-2441, 2006.

Coronato, A., Ercolano, B., Corbella, H., and Tiberi, P.: Glacial, fluvial and volcanic landscape evolution in the Laguna Potrok Aike maar area, Southern Patagonia, Argentina, Quaternary Sci. Rev., 71, 13-26, 2013.

Darling, W. G., Bath, A. H., Gibson, J. J., and Rozanski, K.: Isotopes in water, in: Isotopes in Palaeoenvironmental Research, edited by: Leng, M. J., Springer, 10, 1-66, 2005.

DeNiro, M. J. and Epstein, S.: Isotopic composition of cellulose from aquatic organisms, Geochim. Cosmochim. Ac., 45, 18851894, 1981.

Denton, G. H., Anderson, R. F., Toggweiler, J. R., Edwards, R. L., Schaefer, J. M., and Putnam, A. E.: The Last Glacial Termination, Science, 328, 1652-1656, 2010.

Deplazes, G., Lückge, A., Peterson, L. C., Timmermann, A., Hamann, Y., Hughen, K. A., Röhl, U., Laj, C., Cane, M. A., Sigman, D. M., and Haug, G. H.: Links between tropical rainfall and north Atlantic climate during the last glacial period, Nat. Geosci., 6, 213-217, 2013.

Edwards, T. W. D., Wolfe, B. B., Gibson, J. J., and Hammarlund, D.: Use of water isotope tracers in high latitude hydrology and paleohydrology, in: Long-term Environmental Change in Arctic and Antarctic lakes, edited by: Pienitz, R., Douglas, M. S. V., and Smol, J. P., Springer, 8, 187-207, 2004.

EPICA Community Members: One-to-one coupling of glacial climate variability in Greenland and Antarctica, Nature, 444, 195198, 2006.

Epstein, S., Thompson, P., and Yapp, C. J.: Oxygen and hydrogen isotopic ratios in plant cellulose, Science, 198, 1209-1215, 1977.

Frahm, J-P.: Aquatic mossballs of Blindia inundata in Patagonia, The Bryologist, 104, 502-503, 2001.

Garreaud, R., Lopez, P., Minvielle, M., and Rojas, M.: Large-scale control on the Patagonian climate, J. Climate, 26, 215-230, 2013.

Gat, J. R.: Isotope Hydrology: A study of the water cycle, Imperial College Press, London, 1-185, 2010.

Gebhardt, A. C., Ohlendorf, C., Niessen, F., De Batist, M., Anselmetti, F. S., Ariztegui, D., Kliem, P., Wastegård, S., and Zolitschka, B.: Seismic evidence of up to $200 \mathrm{~m}$ lake-level change in Southern Patagonia since Marine Isotope Stage 4, Sedimentology, 59, 1087-1100, 2012.

Gersonde, R., Crosta, X., Abelmann, A., and Armand, L.: Seasurface temperature and sea ice distribution of the Southern Ocean at the EPILOG Last Glacial Maximum - a circumAntarctic view based on siliceous microfossil records, Quaternary Sci. Rev., 24, 869-896, 2005.

Glasser, N. F., Jansson, K. N., Harrison, S., and Kleman, J.: The glacial geomorphology and Pleistocene history of South America between $38^{\circ} \mathrm{S}$ and $56^{\circ} \mathrm{S}$, Quaternary Sci. Rev., 27, 365-390, 2008.

Gourcy, L. L., Groening, M., and Aggarwal, P. K.: Stable oxygen and hydrogen isotopes, in: Isotopes in the water cycle: past, present and future of a developing science, edited by: Aggarwal, P. K., Gat, J. R., and Froehlich, K. F. O., Springer, Dordrecht, 39-52, 2005.

Haberzettl, T., Corbella, H., Fey, M., Janssen, S., Lücke, A., Mayr, C., Ohlendorf, C., Schäbitz, F., Schleser, G., Wille, M., Wulf, S., and Zolitschka, B.: Lateglacial and Holocene wet-dry cycles in southern Patagonia: chronology, sedimentology and geochemistry of a lacustrine record from Laguna Potrok Aike, Argentina, The Holocene, 17, 297-310, 2007.

Haberzettl, T., Kück, B., Wulf, S., Anselmetti, F., Ariztegui, D., Corbella, H., Fey, M., Janssen, S., Lücke, A., Mayr, C., Ohlendorf, C., Schäbitz, F., Schleser, G. H., Wille, M., and Zolitschka, B.: Hydrological variability in southeastern Patagonia and explosive volcanic activity in the southern Andean Cordillera during Oxygen Isotope Stage 3 and the Holocene inferred from lake sediments of Laguna Potrok Aike, Argentina, Palaeogeogr. Palaeocl. Palaeocl., 259, 213-229, 2008.

Hahn, A., Kliem, P., Ohlendorf, C., Zolitschka, B., Rosén, P., and the PASADO Science Team: Climate induced changes as registered in inorganic and organic sediment components from Laguna Potrok Aike (Argentina) during the past $51 \mathrm{ka}$, Quaternary Sci. Rev., 71, 154-166, 2013.

Hedenäs, L.: The Drepanocladus s. str. species with excurrent costae (Amblystegiaceae), Nova Hedwigia, 64, 535-547, 1997.

Heusser, C. J., Southern westerlies during the Last Glacial Maximum, Quaternary Res., 31, 423-425, 1989.

Hogg, A, Hua, Q., Blackwell, P., Niu, M., Buck, C., Guilderson, T., Heaton, T., Palmer, J., Reimer, P., Reimer, R., Turney, C., and Zimmerman, S.: SHCal13 Southern Hemisphere Calibration, 050000 years cal BP, Radiocarbon, 55, 1889-1903, 2013.

Hubbard, A., Hein, A. S., Kaplan, M. R., Hulton, N. R. J., and Glasser, N.: A modeling reconstruction of the last glacial maximum ice sheet and its deglaciation in the vincinity of the northern Patagonian icefeld, South America, Geogr. Ann. A, 87, 375-391, 2005.

Hulton, N. R. J., Purves, R. S., McCulloch, R. D., Sugden, D. E., and Bentley, M. J.: The Last Glacial Maximum and deglaciation in southern South America, Quaternary Sci. Rev., 21, 233-241, 2002.

Jouzel, J., Hoffmann, G., Koster, R. D., and Masson, V.: Water isotopes in precipitation: data/model intercomparison for presentday and past climates, Quaternary Sci. Rev., 19, 363-379, 2000.

Jouzel, J., Vimeux, F., Caillon, N., Delaygue, G., Hoffmann, G., Masson-Delmotte, V., and Parrenin, F.: Magnitude of isotope/temperature scaling for interpretation of central Antarctic ice cores, J. Geophys. Res., 108, doi:10.1029/2002JD002677, 2003.

Kilian, R. and Lamy, F.: A review of Glacial and Holocene paleoclimate records from southernmost Patagonia $\left(49-55^{\circ} \mathrm{S}\right)$, Quaternary Sci. Rev., 53, 1-23, 2012.

Kliem, P., Buylaert, J. P., Hahn, A., Mayr, C., Murray, A. S., Ohlendorf, C., Veres, D., Wastegård, S., Zolitschka, B., and the PASADO science team: Magnitude, geomorphologic response and climate links of lake level oscillations at Laguna Potrok Aike, Patagonian steppe (Argentina), Quaternary Sci. Rev., 71, 131146, 2013a.

Kliem, P., Enters, D., Hahn, A., Ohlendorf, C., Lisé-Pronovost, A., St-Onge, G., Wastegård, S., Zolitschka, B., and the PASADO Science Team: Lithology, radiocarbon chronology and sedimentological interpretation of the lacustrine record from Laguna Potrok Aike, southern Patagonia, Quaternary Sci. Rev., 71, 5469, 2013b.

Kohfeld, K. E., Graham, R. M., de Boer, A. M., Sime, L. C., Wolff, E. W., Le Quéré, C., and Bopp, L.: Southern Hemisphere west- 
erly wind changes during the Last Glacial Maximum: paleo-data synthesis, Quaternary Sci. Rev., 68, 76-95, 2013.

Kohn, M. J. and Welker, J. M.: On the temperature correlation of $\delta^{18} \mathrm{O}$ in modern precipitation, Earth Planet. Sc. Lett., 231, 8796, 2005.

Lamy, F., Hebbeln, D., and Wefer, G.: High-resolution marine record of climatic change in mid-latitude Chile during the last 28000 years based on terrigenous sediment parameters, Quaternary Res., 51, 83-93, 1999.

Lamy, F., Kaiser, J., Arz, H. W., Hebbeln, D., Ninnemann, U., Timm, O., Timmermann, A., and Toggweiler, J. R.: Modulation of the bipolar seasaw in the Southeast Pacific during Termination 1, Earth Planet. Sc. Lett., 259, 400-413, 2007.

Lea, D. W., Martin, P. A., Pak, D. K., and Spero, H. J.: Reconstructing a $350 \mathrm{ky}$ history of sea level using planktonic $\mathrm{Mg} / \mathrm{Ca}$ and oxygen isotope records from a Cocos Ridge core, Quaternary Sci. Rev., 21, 283-293, 2002.

Lee, J.-E., Fung, I., DePaolo, D.J., and Otto-Bliesner, B.: Water isotopes during the Last Glacial Maximum: New general circulation model calculations. J. Geophys. Res., 113, 1-15, doi:10.1029/2008JD009859, 2008.

Markgraf, V. and Huber, U. M.: Late and postglacial vegetation and fire history in Southern Patagonia and Tierra del Fuego, Palaeogeogr. Palaeocl. Palaeoec., 297, 351-366, 2010.

Mayr, C., Lücke, A., Stichler, W., Trimborn, P., Ercolano, B., Oliva, G., Ohlendorf, C., Soto, J., Fey, M., Haberzettl, T., Janssen, S., Schäbitz, F., Schleser, G., Wille, M., and Zolitschka, B.: Precipitation origin and evaporation of lakes in semi-arid Patagonia (Argentina) inferred from stable isotopes $\left(\delta^{18} \mathrm{O}, \delta^{2} \mathrm{H}\right)$, J. Hydrol., 334, 53-63, 2007.

Mayr, C., Lücke, A., Wagner, S., Wissel, H., Ohlendorf, C., Haberzettl, T., Oehlerich, M., Schäbitz, F., Wille, M., Zhu, J., and Zolitschka, B.: Intensified Southern Hemisphere Westerlies regulated atmospheric $\mathrm{CO}_{2}$ during the last deglaciation, Geology, 41, 831-834, 2013.

McCulloch, R. D., Fogwill, C. J., Sugden, D. E., Bentley, M. J., and Kubik, P. W.: Chronology of the last glaciation in central Strait of Magellan and Bahía Inútil, southernmost South America, Geogr. Ann. A, 87, 289-312, 2005.

Moreno, P. I., Lowell, T. V., Jacobson, Jr. G. L., and Denton, G. H.: Abrupt vegetation and climate changes during the Last Glacial Maximum and last termination in the Chilean Lake District: A case study from Canal de la Puntilla ( $\left.41^{\circ} \mathrm{S}\right)$, Geogr. Ann. A, 81, 285-311, 1999.

Moreno, P. I., Francois, J. P., Moy, C. M., and Villa-Martínez, R.: Covariability of the Southern Westerlies and atmospheric $\mathrm{CO}_{2}$ during the Holocene, Geology, 38, 727-730, 2010.

Moreno, P. I., Villa-Martínez, R., Cárdenas, M. L., and Sagredo, E. A.: Deglacial changes of the southern margin of the southern westerly winds revealed by terrestrial records from SW Patagonia $\left(52^{\circ} \mathrm{S}\right)$, Quaternary Sci. Rev., 41, 1-21, 2012.

Moschen, R., Kühl, N., Rehberger, I., and Lücke, A.: Stable carbon and oxygen isotopes in sub-fossil Sphagnum: Assessment of their applicability for palaeoclimatology, Chem. Geol., 259, 262-272, 2009.

Ochyra, R. and Lightowlers, P. J.: The South Georgian moss flora Vittia, Brit. Antarct. Surv. B., 80, 121-127, 1988.

Ohlendorf, C., Gebhardt, C., Hahn, A., Kliem, P., Zolitschka, B., and the PASADO Science Team: The PASADO core processing strategy - A proposed new protocol for sediment core treatment in multidisciplinary lake drilling projects, Sediment. Geol., 239, 104-115, 2011.

Ohlendorf, C., Fey, M., Gebhardt, C., Haberzettl, T., Lücke, A., Mayr, C., Schäbitz, F., Wille, M., and Zolitschka, B.: Mechanisms of lake-level change at Laguna Potrok Aike (Argentina) insights from hydrological balance calculations, Quaternary Sci. Rev., 71, 27-45, 2013.

Paruelo, J., Beltrán, A., Jobbágy, E., Sala, O., and Golluscio, R.: The climate of Patagonia: general patterns and controls on biotic processes, Ecología Australia, 8, 85-101, 1998.

Pendall, E., Markgraf, V., White, J. W. C., and Dreier, M.: Multiproxy record of Late Pleistocene-Holocene climate and vegetation changes from a peat bog in Patagonia, Quaternary Res., 55, 168-178, 2001.

Pollock, E. W. and Bush, A. B. G.: Atmospheric simulations of southern South America's climate since the Last Glacial maximum, Quaternary Sci. Rev., 71, 219-228, 2013.

Rasmussen, S. O., Andersen, K. K., Svensson, A. M., Steffensen, J. P., Vinther, B. M., Clausen, H. B., Siggaard-Anderson, M.L., Johnsen, S. J., Larsen, L. B., Dahl-Jensen, D., Bigler, M., Röthlisberger, R., Fischer, H., Goto-Azuma, K., Hansson, M. E., and Ruth, U.: A new Greenland ice core chronology for the last glacial termination, J. Geophys. Res., 111, D06102, doi:10.1029/2005JD006079, 2006.

Recasens, C., Ariztegui, D., Gebhardt, C., Gogorza, C., Haberzettl, T., Hahn, A., Kliem, P., Lisé-Pronovost, A., Lücke, A. Maidana, N. I., Mayr, C., Ohlendorf, C., Schäbitz, F., St-Onge, G., Wille, M., Zolitschka, B., and the PASADO Science Team: New insights into paleoenvironmental changes in Laguna Potrok Aike, Southern Patagonia, since the Late Pleistocene: the PASADO multiproxy record, The Holocene, 22, 1323-1335, 2012.

Risi, C., Bony, S., Vimeux, F., and Jouzel, J.: Water-stable isotopes in the LMDZ4 general circulation model: Model evaluation for present-day and past climates and applications to climatic interpretations of tropical isotopic records. J. Geophys. Res., 115, 127, doi:10.1029/2009JD013255, 2010.

Rojas, M.: Sensitivity of Southern Hemisphere circulation to LGM and $4 \times \mathrm{CO}_{2}$ climates, Geophys. Res. Lett., 40, 965-970, 2013.

Rojas, M., Moreno, P., Kageyama, M., Crucifix, M., Hewitt, C., Abe-Ouchi, A., Ohgaito, R., Brady, E. C., and Hope, P.: The Southern Westerlies during the last glacial maximum in PMIP2 simulations, Clim. Dynam., 32, 525-548, 2009.

Rozanski, K., Araguás-Araguás, L., and Gonfiantini, R.: Relation between long-term trends of oxygen-18 isotope composition of precipitation and climate, Science, 258, 981-985, 1992.

Rozanski, K., Araguás-Araguás, L., and Gonfiantini, R.: Isotopic Patterns in Modern Global precipitation, in: Climate Change in Continental Isotopic Records, edited by: Swart, P. K., Lohmann, K. L., McKenzie, J., and Savin, S., Geophysical Monograph 78, American Geophysical Union, Washington DC, 1-37, 1993.

Sagredo, E. A., Moreno, P. I., Villa-Martínez, R., Kaplan, M. R., Kubik, P. W., and Stern, C. R.: Fluctuations of the Última Esperanza ice lobe $\left(52^{\circ} \mathrm{S}\right)$, Chilean Patagonia, during the last glacial maximum and termination 1, Geomorphology, 125, 92108, 2011.

Sauer, P. E., Miller, G. H., and Overpeck, J. T.: Oxygen isotope ratios of organic matter in Arctic lakes as a paleoclimate proxy: 
field and laboratory investigations, J. Paleolimnol., 25, 43-64, 2001.

Schmidt, G. A., LeGrande, A. N., and Hoffmann, G.: Water isotope expressions of intrinsic and forced variability in a coupled ocean-atmosphere model. J. Geophys. Res., 112, 1-18, doi:10.1029/2006JD007781, 2007.

Schmitt, J., Schneider, R., Elsig, J., Leuenberger, D., Lourantou, A., Chappellaz, J., Köhler, P., Joos, F., Stocker, T. F., Leuenberger, M., and Fischer, H.: Carbon Isotope Constraints on the Deglacial $\mathrm{CO}_{2}$ Rise from Ice Cores, Science, 336, 711-714, 2012.

Schneider, C., Glaser, M., Kilian, R., Santana, A., Butorovic, N., and Casassa, G.: Weather observations across the Southern Andes at 53 S, Phys. Geogr., 24, 97-119, 2003.

Sime, L. C., Kohfeld, K. E., Le Quéré, C., Wolff, E. W., de Boer, A. M., Graham, R. M., and Bopp, L.: Southern Hemisphere westerly wind changes during the Last Glacial Maximum: model-data comparison, Quaternary Sci. Rev., 68, 104-120, 2013.

Solari, M. A., Le Roux, J. P., Hervé, F., Airo, A., and Calderón, M.: Evolution of the Great Tehuelche Paleolake in the Torres del Paine National Park of Chilean Patagonia during the Last Glacial Maximum and Holocene, Andean Geol., 39, 1-21, 2012.

Stern, C. R.: Holocene tephrochronology record of large explosive eruptions in southernmost Patagonian Andes, B. Volcanol., 70, 435-454, 2008

Sternberg, L. and Ellsworth, P. F. V.: Divergent Biochemical Fractionation, Not Convergent Temperature, Explains Cellulose Oxygen Isotope Enrichment across Latitudes, PLoS ONE, 6, e28040, doi:10.1371/journal.pone.0028040, 2011.

Sternberg, L. S. L.: Oxygen and hydrogen isotope ratios in plant cellulose: mechanisms and applications, in: Stable isotope in ecological research, Ecological studies 68, edited by: Rundel, P. W., Ehleringer, J. R., and Nagy, K. A., Springer, New York, 124-141, 1989.

Sternberg, L. S. L.: Oxygen stable isotope ratios of tree-ring cellulose: the next phase of understanding, New Phytol., 181, 553$562,2009$.

Sturm, C., Zhang, Q., and Noone, D.: An introduction to stable water isotopes in climate models: benefits of forward proxy modelling for palaeoclimatology, Clim. Past, 6, 115-129, 2010, http://www.clim-past.net/6/115/2010/.

Teranes, J. L. and McKenzie, J. A.: Lacustrine oxygen isotope record of 20th-century climate change in central Europe: evaluation of climatic controls on oxygen isotopes in precipitation, $\mathrm{J}$. Paleolimnol., 26, 131-146, 2001.

Toggweiler, J. R., Russell, J. L., and Carson, S. R.: Midlatitude westerlies, atmospheric $\mathrm{CO}_{2}$, and climate change during the ice ages, Paleoceanography, 21, PA2005, doi:10.1029/2005PA001154, 2006.

Trombotto, D.: Inventory of fossil cryogenic forms and structures in Patagonia and the mountains of Argentina beyond the Andes, S. Afr. J. Sci., 98, 171-180, 2002.

Valero-Garcés, B., Jenny, B., Rondanelli, M., Delgado-Huertas, A., Burns, S., Veit, H., and Moreno A.: Palaeohydrology of Laguna de Tagua Tagua $\left(34^{\circ} 30^{\prime}\right)$ and moisture fluctuations in Central Chile for the last $46000 \mathrm{yr}$, J. Quaternary Sci., 20, 625-641, 2005.
Villa-Martínez, R., Moreno, P. I., and Valenzuela, M. A.: Deglacial and postglacial vegetation changes on the eastern slopes of the central Patagonian Andes (47 S), Quaternary Sci. Rev., 32, 8699, 2012.

Wagner, S., Widmann, M., Jones, J., Haberzettl, T., Lücke, A., Mayr, C., Ohlendorf, C., Schäbitz, F., and Zolitschka, B.: Transient simulations, empirical reconstructions and forcing mechanisms for the Mid-holocene hydrological climate in southern Patagonia, Clim. Dynam., 29, 333-355, 2007.

WAIS Divide Project Members: Onset of deglacial warming in West Antarctica driven by local orbital forcing, Nature, 500, 440-446, 2013.

Wang, X., Auler, A. S., Edwards, R. L., Cheng, H., Ito, E., Wang, Y., Kong, X., and Solheid, M.: Millennial-scale precipitation changes in southern Brazil over the past 90,000 years, Geophys. Res. Lett., 34, L23701, doi:10.1029/2007GL031149, 2007.

Wastegård, S., Veres, D., Kliem, P., Ohlendorf, C., Zolitschka, B., and the PASADO Science Team: Towards a late Quaternary tephrochronological framework for the southernmost part of South America - the Laguna Potrok Aike tephra record, Quaternary Sci. Rev., 71, 81-90, 2013.

Wille, M., Maidana, N., Schäbitz, F., Fey, M., Haberzettl, T., Janssen, S., Lücke, A., Mayr, C., Ohlendorf, C., Schleser, G., and Zolitschka, B.: Vegetation and climate dynamics in Southern South America: the microfossil record of Laguna Potrok Aike, Santa Cruz, Argentina, Rev. Palaeobot. Palyno., 146, 234-246, 2007.

Williams, G. P. and Bryan, K.: Ice Age Winds: An Aquaplanet Model, J. Climate, 19, 1706-1715, 2006.

Wissel, H., Mayr, C., and Lücke, A.: A new approach for the isolation of cellulose from aquatic plant tissue and freshwater sediments for stable isotope analysis, Org. Geochem., 39, 15451561, 2008.

Zhu, J., Lücke, A., Wissel, H., Müller, D., Mayr, C., Ohlendorf, C., Zolitschka, B., and the PASADO Science Team: The last GlacialInterglacial transition in Patagonia, Argentina: the stable isotope record of bulk sedimentary organic matter from Laguna Potrok Aike, Quaternary Sci. Rev., 71, 205-218, 2013.

Zhu, J., Lücke, A., Wissel, H., Mayr, C., Ohlendorf, C., and Zolitschka, B.: Characterizing oxygen isotope variability and host water relation of modern and subfossil aquatic mosses, Geochim. Cosmochim. Ac., 130, 212-228, 2014.

Zolitschka, B., Schäbitz, F., Lücke, A., Corbella, H., Ercolano, B., Fey, M., Haberzettl, T., Janssen, S., Maidana, N., Mayr, C., Ohlendorf, C., Oliva, G., Paez, M. M., Schleser, G. H., Soto, J., Tiberi, P., and Wille, M.: Crater lakes of the Pali Aike Volcanic Field as key sites of paleoclimatic and paleoecological reconstructions in southern Patagonia, Argentina, J. S. Am. Earth Sci., 21, 294-309, 2006.

Zolitschka, B., Anselmetti, F., Ariztegui, D., Corbella, H., Francus, P., Lücke, A., Maidana, N., Ohlendorf, C., Schäbitz, F., and Wastegård, S.: Environment and climate of the last 51000 years - new insights from the Potrok Aike maar lake Sediment Archive Drilling project (PASADO), Quaternary Sci. Rev., 71, 1-12, 2013. 